\title{
Characterization of total ecosystem-scale biogenic VOC exchange at a Mediterranean oak-hornbeam forest
}

\author{
Simon Schallhart ${ }^{1}$, Pekka Rantala ${ }^{1}$, Eiko Nemitz $^{2}$, Ditte Taipale ${ }^{1,3,4}$, Ralf Tillmann ${ }^{5}$, Thomas F. Mentel ${ }^{5}$, \\ Benjamin Loubet $^{6}$, Giacomo Gerosa ${ }^{7}$, Angelo Finco ${ }^{7}$, Janne Rinne ${ }^{1,8,9,10}$, and Taina M. Ruuskanen ${ }^{1}$ \\ ${ }^{1}$ Department of Physics, University of Helsinki, Helsinki, Finland \\ ${ }^{2}$ Centre for Ecology \& Hydrology (CEH), Penicuik, UK \\ ${ }^{3}$ Department of Plant Physiology, Estonian University of Life Sciences, Tartu, Estonia \\ ${ }^{4}$ Department of Forest Sciences, University of Helsinki, Helsinki, Finland \\ ${ }^{5}$ Forschungszentrum Jülich GmbH, Jülich, Germany \\ ${ }^{6}$ National Institute of Agronomic Research UMR ECOSYS INRA, AgroParisTech, Université Paris Saclay, \\ Saint-Aubin, France \\ ${ }^{7}$ Department of Mathematics and Physics, Catholic University of Brescia, Brescia, Italy \\ ${ }^{8}$ Department of Geosciences and Geography, University of Helsinki, Helsinki, Finland \\ ${ }^{9}$ Finnish Meteorological Institute, Helsinki, Finland \\ ${ }^{10}$ Department of Physical Geography and Ecosystem Science, Lund University, Lund, Sweden
}

Correspondence to: Simon Schallhart (simon.schallhart@helsinki.fi)

Received: 21 August 2015 - Published in Atmos. Chem. Phys. Discuss.: 14 October 2015

Revised: 5 April 2016 - Accepted: 16 May 2016 - Published: 10 June 2016

\begin{abstract}
Recently, the number and amount of biogenically emitted volatile organic compounds (VOCs) has been discussed in great detail. Depending on the ecosystem, the published number varies between a dozen and several hundred compounds. We present ecosystem exchange fluxes from a mixed oak-hornbeam forest in the Po Valley, Italy. The fluxes were measured by a proton transfer reaction-timeof-flight (PTR-ToF) mass spectrometer and calculated using the eddy covariance (EC) method. Detectable fluxes were observed for up to 29 compounds, dominated by isoprene, which comprised over $60 \%$ of the total upward flux (on a molar basis). The daily average of the total VOC upward flux was $10.4 \mathrm{nmol} \mathrm{m}^{-2} \mathrm{~s}^{-1}$. Methanol had the highest concentration and accounted for the largest downward flux. Methanol seemed to be deposited to dew, as the downward flux happened in the early morning, right after the calculated surface temperature came closest to the calculated dew point temperature.

We estimated that up to $30 \%$ of the upward flux of methyl vinyl ketone (MVK) and methacrolein (MACR) originated from atmospheric oxidation of isoprene. A comparison between two methods for the flux detection (manual and au-
\end{abstract}

tomated) was made. Their respective advantages and disadvantages were discussed and the differences in their results shown. Both provide comparable results.

\section{Introduction}

Volatile organic compound (VOC) fluxes between vegetation and atmosphere affect atmospheric chemistry by controlling the oxidation capacity of the atmosphere (Fehsenfeld et al., 1992; Fuentes et al., 2000). The non-methane biogenic VOC emissions are dominated by terpenoids, e.g., isoprene and monoterpenes, followed by oxygenated VOCs such as methanol and acetone (Kesselmeier et al., 1999; Guenther et al., 2012). The emitted VOCs are physically removed by dry or wet deposition or are oxidized by, for example, $\mathrm{OH}$, $\mathrm{O}_{3}$ and $\mathrm{NO}_{3}$ (Mogensen et al., 2015). Their oxidation contributes to the tropospheric ozone formation and destruction processes (e.g., Derwent et al., 2003; Bloss et al., 2005), aerosol formation and aerosol growth and thereby influences air quality and climate (Kulmala et al., 1998; Tunved et al., 2006; Monks et al., 2009; Riipinen et al., 2012; Paasonen 
et al., 2013). To assess these effects caused by the biogenic VOCs, reliable flux budgets are necessary.

Most ecosystem-scale VOC flux measurements have been conducted with disjunct eddy covariance method by mass scanning using proton-transfer-reaction quadrupole mass spectrometer (PTR-QMS), relaxed eddy accumulation or surface layer gradient techniques with gas chromatographymass spectrometry applying selected ion mode (e.g., Lamb et al., 1985; Businger and Oncley, 1990; Fuentes et al., 1996; Guenther et al., 1996; Rinne et al., 2001; Karl et al., 2002; Rinne and Ammann, 2012). These methods require pre-selection of target compounds and in the case of the PTRQMS suffer from the limitation of unit mass resolution, making it impossible to separate isobaric compounds, i.e., compounds with identical integer mass but different chemical composition. Thus, measurements have inherently focused on compounds already known to be emitted by vegetation and thereby hinder the discovery of fluxes of compounds not previously known to be emitted by vegetation. Furthermore, extreme weather conditions such as hail can change the VOC flux pattern (Kaser et al., 2013), which is difficult to measure with such methods.

Lately, new insights have been provided by the more universal and sensitive PTR-ToF. Park et al. (2013) analyzed flux data obtained by the PTR-ToF and revealed many previously unobserved compounds to be emitted, but this approach has so far only been applied to very few vegetation types (e.g., Ruuskanen et al., 2011; Park et al., 2013; Kaser et al., 2013).

In this study we have conducted VOC flux measurements at a remnant natural oak-hornbeam-dominated forest (Bosco Fontana) in northern Italy as part of an intensive field campaign organized by the European FP7 project "ÉCLAIRE" (Effects of Climate Change on Air Pollution Impacts and Response Strategies for European Ecosystems). The objectives of the ÉCLAIRE Bosco Fontana experiment were (a) to quantify the exchange of a range of pollutants with this ecosystem in one of the most polluted regions of Europe, (b) to assess the importance of in-canopy chemical interactions on the biosphere-atmosphere exchange of reactive gases and aerosols and (c) to provide a supersite in the framework of a spatial Po Valley study that combined resources from two EU projects (ÉCLAIRE and PEGASOS - PanEuropean Gas-AeroSOls-climate interaction Study) with a national Italian initiative.

In this paper, we present the results of the application of state-of-the-art PTR-ToF mass spectrometry and eddy covariance technique to derive the total biogenic VOC flux above the Bosco Fontana ecosystem. The aims of this study were (i) the comparison of two data-processing approaches to identify compounds for which fluxes were above the detection limit, contrasting the automated method used by Park et al. (2013) with the manual method, which uses manual cross covariance peak checking (e.g., Taipale et al., 2010; Ruuskanen et al., 2011; Kaser et al., 2013); (ii) the characterization of the total ecosystem-scale VOC flux from a Mediterranean oak forest, with particular emphasis on (iii) the quantification of the contribution of non-terpenoid VOCs to the total VOC flux; (iv) the estimation of the possible contribution of secondary compounds to the observed above-canopy fluxes; and (v) the study of dew potentially causing methanol deposition in the morning.

A companion paper (Acton et al., 2016) compares the PTR-ToF-MS measurements with simultaneous measurements by PTR-QMS and a bottom-up estimate of the canopy flux scaled up from leaf-level emission measurements, and also derives emission factors for the use in emissions models.

\section{Materials and methods}

\subsection{Bosco Fontana site description}

The measurements were performed from 15 June to 6 July 2012 in Bosco Fontana, Lombardy, Italy. Bosco Fontana is a 233 ha forested nature reserve located in the northeast of the Po Valley. The main tree species are Quercus cerris (turkey oak), Quercus robur (pedunculate oak), Quercus rubra (northern red oak) and Carpinus betulus (hornbeam) (Dalponte et al., 2008). The typical height of the trees varied between 26 and $28 \mathrm{~m}$. The surroundings of the Bosco Fontana forest area are agricultural land and some roads. The largest city nearby is Mantua, with 48000 inhabitants, which is located $8 \mathrm{~km}$ to the southeast. The measurement site is $25 \mathrm{~m}$ above sea the level. The temperatures varied from 18 to $32{ }^{\circ} \mathrm{C}$ during the campaign and the main wind directions were east and west. The measurement tower was $42 \mathrm{~m}$ high and located in the southwestern part of the nature reserve $\left(45.20^{\circ} \mathrm{N}, 10.74^{\circ} \mathrm{E}\right)$. Figure 1 shows a satellite image of the area, with the position of the tower and the mean $80 \%$ footprint (Acton et al., 2016). The climatological mean annual temperature is $13.3^{\circ} \mathrm{C}$ and the mean annual precipitation is $834 \mathrm{~mm}$ (Willmott and Matsuura, 2012a, b).

\subsection{Meteorological and trace gas data}

The measurement tower was equipped with temperature and relative humidity sensors at several heights. The turbulence data were measured with a 3-D anemometer (HS 50, Gill Instruments) at $32 \mathrm{~m}$ above ground level (hereafter a.g.l.) and the instrument was fastened on a pole $1.7 \mathrm{~m}$ away from the lattice tower. An additional measurement of wind direction was provided by a 2-D ultrasonic anemometer as part of an integrated weather station (Weather Transmitter WXT610, Vaisala; $32 \mathrm{~m}$ a.g.l.), which also measured air pressure, relative humidity and temperature. The $\mathrm{O}_{3}$ concentration was determined with a chemiluminescence analyzer (model 202, 2B Technologies) at $40 \mathrm{~m}$ a.g.l. and $\mathrm{NO}_{2}$ and $\mathrm{NO}$ with a chemiluminescence analyzer equipped with a thermal converter (model 42C, Thermo Scientific) at a height of $32 \mathrm{~m}$ a.g.l. 


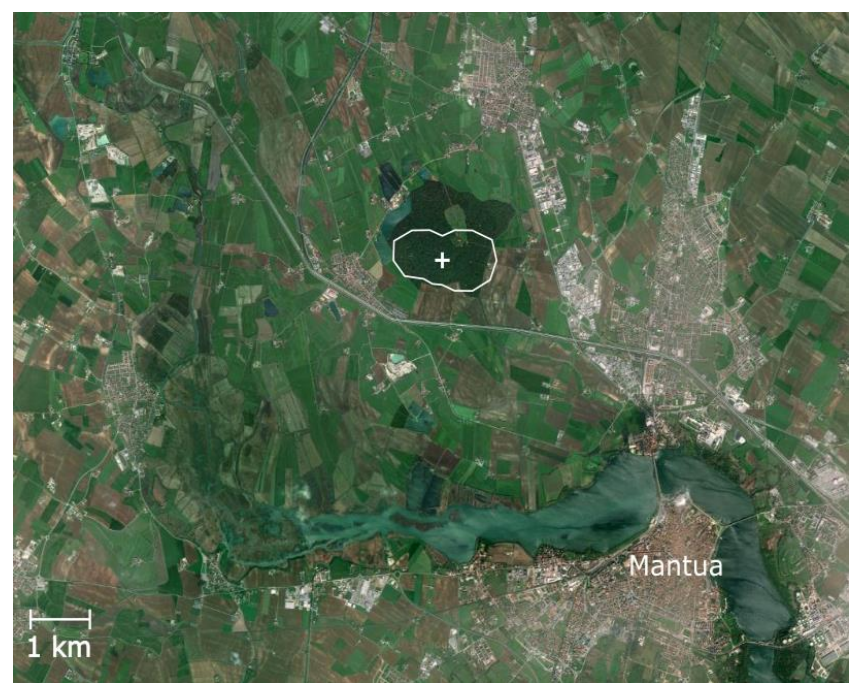

Figure 1. Satellite picture (imagery ${ }^{\circledR} 2015$ Cnes/Spot Image, DigitalGlobe, European Space Imaging, Landsat, map data ${ }^{\odot} 2015$ Google) of the Bosco Fontana national park and the surroundings. The position of the flux tower is marked by a white cross and surrounded by the mean $80 \%$ of the flux footprint, which is represented by the white line (Acton et al., 2016). The dark green surrounding is the forest area of the national park.

Carbon dioxide flux measurements were performed, using the eddy covariance technique, at the top of the tower, where a sonic anemometer (USA 1, Metek) and a fast IRGA analyzer (model 7500, LICOR) were mounted on a pole, at a distance of $1.7 \mathrm{~m}$ from the edge of the tower. The sonic anemometer was working at $20 \mathrm{~Hz}$ and the fast IRGA was calibrated before and after the field campaign and no significant drift was observed. Carbon dioxide fluxes were measured from 18 June to 12 July. Several procedures were applied in order to obtain the correct flux calculations: despiking (Vickers and Mahrt, 1997), double rotation of the reference system (Kaimal and Finnigan, 1994), linear detrending (Lee at al., 2004), frequency loss corrections using the ogive methodology (Ammann et al., 2006), Webb-PearmanLeuning (WPL) corrections for density fluctuations (Webb et al., 1980), and stationarity test (Foken and Wichura, 1996); finally, a manual selection of the data was performed too and data after rainfalls were discarded.

The dew point temperature, $T_{\mathrm{d}}$, was calculated according to Lawrence (2005):

$T_{\mathrm{d}}=T\left[1-\frac{T \ln \left(\frac{\mathrm{RH}}{100}\right)}{\frac{L_{\mathrm{vap}}}{R_{\mathrm{w}}}}\right]^{-1}$,

where $T$ is the ambient temperature, $\mathrm{RH}$ is the relative humidity, $L_{\mathrm{vap}}$ is the enthalpy of vaporization $\left(2.501 \times 10^{6} \mathrm{~J} \mathrm{~kg}^{-1}\right)$ and $R_{\mathrm{W}}$ is the gas constant of water vapor $\left(461.5 \mathrm{~J} \mathrm{~K}^{-1} \mathrm{~kg}^{-1}\right)$.
The average aerodynamic temperature $T\left(z_{0}^{\prime}\right)$ was estimated using a method described by Nemitz et al. (2009) as

$T\left(z_{0}^{\prime}\right)=T+\overline{\theta^{\prime} w^{\prime}}\left(R_{\mathrm{a}}+R_{\mathrm{b}}\right)$,

where $z_{0}^{\prime}$ is the notional mean height of the canopy exchange, $\overline{\theta^{\prime} w^{\prime}}$ and $T$ are the measured heat flux and temperature at the measurement height of $z_{\mathrm{m}}$, respectively. In this study, the roughness length $\mathrm{z}_{0}$ was estimated to be ca. $1 \mathrm{~m}$ (e.g., Dolman, 1986). For the zero displacement height $d$ we used the common approximation of $d=2 / 3 \times z_{\mathrm{c}}$, where $z_{\mathrm{c}}$ is the canopy height $(28 \mathrm{~m})$.

The resistance parameters $R_{a}$ and $R_{b}$ were determined as (Owen and Thompson, 1963; Garland, 1977)

$R_{\mathrm{a}}=\frac{u}{u_{*}^{2}}-\frac{\Psi_{h}\left(\frac{z_{\mathrm{m}}-d}{L}\right)-\Psi_{\mathrm{m}}\left(\frac{z_{\mathrm{m}}-d}{L}\right)}{k u_{*}}$

and

$R_{\mathrm{b}}=\left(B u_{*}\right)^{-1}$,

where $L$ is the Obukhov length. The sublayer-Stanton number $(B)$ can be estimated by

$B^{-1}=1.45 R e_{*}^{0.24} S c^{0.8}$,

where roughness Reynolds number, $R e_{*}$, is given by

$R e_{*}=\frac{z_{0} u_{*}}{v}$

and the Schmidt number, $S c$, by

$S c=\frac{v}{D}$.

The friction velocity $u_{*}$ and the horizontal wind $u$ were taken from the measurements at $z_{\mathrm{m}}$ and $k$ is von Kármán's constant (0.4). The kinematic viscosity of air, $v$, was assumed to be constant $\left(\approx 1.56 \times 10^{-5} \mathrm{~m}^{2} \mathrm{~s}^{-1}\right)$, as was the thermal diffusivity temperature in air, $D\left(\approx 1.9 \times 10^{-5} \mathrm{~m}^{2} \mathrm{~s}^{-1}\right)$. The integral stability correction functions $\Psi_{\mathrm{h}}$ and $\Psi_{\mathrm{m}}$ for heat $(\mathrm{h})$ and momentum $(\mathrm{m})$, respectively, were taken from Rannik (1998).

\subsection{VOC measurements}

\subsubsection{PTR-ToF measurements}

The PTR-ToF (Ionicon Analytik GmbH; Graus et al., 2010; Jordan et al., 2009) combines the soft ionization of a PTR source with the high mass resolution of a time-of-flight mass spectrometer $\sim 4500 \mathrm{~m} / \Delta \mathrm{m}$ (determined as the full width at half maximum of the ion peak). The precise mass of a compound can be derived from the time of flight and the elemental composition can be calculated from the observed mass defect. Therefore the instrument can separate isobaric compounds. It cannot, however, distinguish between isomeric 
compounds, as it gives no information about the compound structure. The real-time measure of full spectra at $10 \mathrm{~Hz}$ allows for flux measurements with the eddy covariance technique.

The PTR-ToF was placed inside a container next to the measurement tower. Air from $32 \mathrm{~m}$ height was sampled through a $40 \mathrm{~m}$ long and $9.5 \mathrm{~mm}$ wide (inner diameter; i.d.) PTFE tube (hereafter referred to as common sampling line), which was pumped at $63 \mathrm{~L} \mathrm{~min}^{-1}$. The pressure drop induced by the pumping was sufficient to prevent condensation in the sampling line outside of the container. Inside the air-conditioned container, the inlet line was heated (selfregulated heating wire with $11 \mathrm{~W} \mathrm{~m}^{-1}$ at $30^{\circ} \mathrm{C}$ ). The 3-D wind measurements were obtained with a frequency of $10 \mathrm{~Hz}$ $10 \mathrm{~cm}$ above the inlet.

The PTR-ToF was connected to the inlet line via a threeway valve (type 6606 with ETFE, Bürkert GmbH \& Co. $\mathrm{KG}$ ), from where a subsample of $0.5 \mathrm{~L} \mathrm{~min}^{-1}$ was pumped through a $1.6 \mathrm{~mm}$ (i.d.) and $1 \mathrm{~mm}$ (i.d.) PEEK capillary (together around $20 \mathrm{~cm}$ long; heated between 40 and $60^{\circ} \mathrm{C}$ ) to the instrument. The PTR-ToF used a $30 \mathrm{~mL} \mathrm{~min}^{-1}$ flow for analysis, the remaining flow was discarded and served only as a by-pass flow in order to decrease the response time of the PTR-ToF and associated wall losses in the inlet capillaries. The drift tube was operated at $600 \mathrm{~V}$ and temperature of $60^{\circ} \mathrm{C}$. Together with a drift tube pressure of $2.3 \mathrm{mbar}$ this resulted in an $E_{\mathrm{PTR}} / N$ ratio of $130 \mathrm{Td}$, where $E_{\mathrm{PTR}}$ is the electrical field strength and $N$ is the gas number density. The instrument produced a time series of 22 days, with a 1.5-day break when the air-conditioning in the container failed.

\subsubsection{Calibration and concentration calculation}

The instrument background was measured one to three times per day. A small pump (N86KNE, KNF Neuberger) established a $1.4 \mathrm{~L} \mathrm{~min}^{-1}$ flow from the common sampling line to a custom-made catalytic converter. This converter was heated to $350^{\circ} \mathrm{C}$ and created VOC-free (zero-) air at ambient humidity. The zero air was connected to the second port of the three way valve and passed an overflow in order to achieve a constant zero-air flow at a constant pressure (Fig. 2). The background measurements were used for the calculations of the concentrations as well as the determination of the limit of detection.

The instrument was calibrated every second week, i.e., a total of three times. A custom-built calibration unit, which mixed zero air with the calibration gas, was inserted between the catalytic converter and the overflow (Fig. 2). The calibration gas (Apel Riemer Environmental Inc.) contained 16 different compounds with the mass range from 33 to $180 \mathrm{amu}$ at known concentrations of around $1 \mathrm{ppm}$. As the gas was diluted with zero air (calibration gas: $10 \mathrm{~mL} \mathrm{~min}^{-1}$; zero air: $1.4 \mathrm{~L} \mathrm{~min}^{-1}$ ) the resulting mixing ratios were around $7 \mathrm{ppb}$. The sensitivities were calculated from the observed count rates of the zero air and the calibration gas measure-

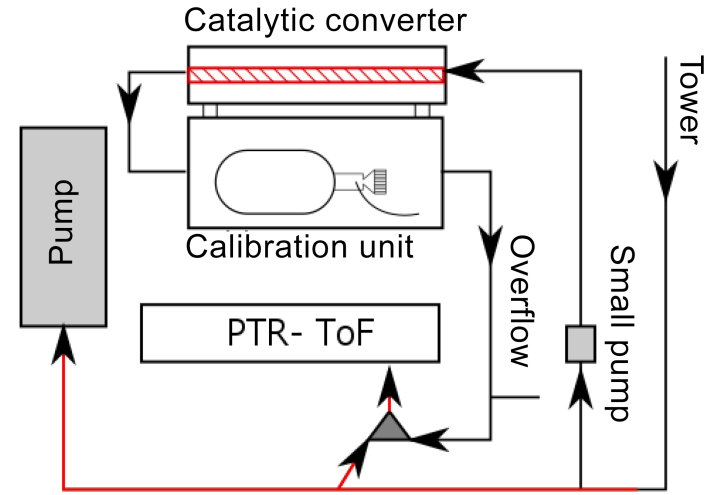

Figure 2. Schematic diagram of the inlet of the PTR-ToF used for the VOC measurements. Red lines indicate heated tubing.

ments in the ppb range. For the VOCs that were not included in our calibration standard, we used average sensitivities for compound families $\mathrm{C}_{x} \mathrm{H}_{y}$ (based on isoprene, benzene, toluene, $o$-xylene, trimethylbenzene, naphthalene, $\alpha$-pinene combined with $\mathrm{C}_{6} \mathrm{H}_{9}^{+}$fragment), $\mathrm{C}_{x} \mathrm{H}_{y} \mathrm{O}_{z}$ (considering acetaldehyde, acrolein, acetone, 2-butanone) and $\mathrm{C}_{x} \mathrm{H}_{y} \mathrm{~N}_{z}$ (set to that of acetonitrile). The averaged sensitivities were $\mathrm{C}_{x} \mathrm{H}_{y}$ $=13( \pm 1.7) \mathrm{ncps} \mathrm{ppb}^{-1}, \mathrm{C}_{x} \mathrm{H}_{y} \mathrm{O}_{z}=19.1( \pm 1.3) \mathrm{ncps} \mathrm{ppb}^{-1}$ and $\mathrm{C}_{x} \mathrm{H}_{y} \mathrm{~N}_{z}=18.1( \pm 1.3) \mathrm{ncps} \mathrm{ppb}^{-1}$. The ranges given in the brackets are the standard deviations of the average sensitivities calculated for the compounds in each group from the calibrations. Normalized counts per second (ncps) have been corrected for transmission (pusher duty cycle losses) and primary ion fluctuations (Herbig et al., 2009). The average signal of the primary ion signal (upscaled via the isotope $\mathrm{H}_{3}^{18} \mathrm{O}_{1}^{+}$) was around $750000 \mathrm{cps}$ (transmission corrected: $\left.10^{7} \mathrm{cps}\right)$. The impurities were $\mathrm{O}_{2}^{+} 4 \%$ and $\mathrm{NO}^{+} 0.3 \%$ of the $\mathrm{H}_{3} \mathrm{O}^{+}$primary ion. The monoterpene sensitivities were derived from the $\alpha$-pinene calibrations (in the calibration gas). Fragments from compounds in the calibration standard were not taken into account when calculating the sensitivities. For example, the signal at $\mathrm{C}_{5} \mathrm{H}_{9}^{+}(\mathrm{m} / z 69.0699)$ relates to the protonated parent ion of isoprene and is scaled up to the total isoprene, although some isoprene fragments also show up at other masses. As a consequence, it is important that fluxes at those fragments are excluded to avoid double counting. The result of this procedure can be found in Table A1 in the Appendix.

For compounds/fragments not included in the calibration standard, the average sensitivities for the compound families are applied as previously described. In this case the fragmentation pattern is not accounted for and all fragments have to be added up to arrive at the total flux, excluding those that could be associated with calibrated compounds. Two exceptions were made: the sensitivity for acetic acid was halved $\left(9.55 \mathrm{ncps} \mathrm{ppb}^{-1}\right)$ as it was not calibrated and its major fragment $\left(\mathrm{C}_{2} \mathrm{H}_{3} \mathrm{O}^{+}\right.$; Baasandorj et al., 2015) was disregarded. For ethanol $\left(\mathrm{C}_{2} \mathrm{H}_{7} \mathrm{O}_{1}^{+}\right)$the methanol sensitivity was used. 
For the data post-processing the ToF Analyzer V2.45 software was used, which has been described in Müller et al. $(2010,2013)$. A peak list (Table A1) was created with the TofTool software (Junninen et al., 2010) by integrating the $10 \mathrm{~Hz}$ raw data for $1 \mathrm{~h}$ and then fitting and identifying the different peaks. The measured mass peaks were identified by matching them with the calculated masses of different combinations of $\mathrm{H}, \mathrm{C}, \mathrm{O}, \mathrm{N}$ and $\mathrm{S}$ atoms. The range of atoms allowed to appear in a compound was set from 0 to 50.

After peak fitting was performed on the $10 \mathrm{~Hz}$ data the output of the ToF analyzer were aggregated to provide $30 \mathrm{~min}$ concentration data in a three-step process. First, the $10 \mathrm{~Hz}$ data were averaged over $30 \mathrm{~min}$. Second, from these $30 \mathrm{~min}$ data the zero-air measurements were subtracted, wherein values for the times between the zero-air measurements were linearly interpolated. The resulting signals were then compared to the limit of detection LOD $=2 \sigma_{\text {zero }}$, where $\sigma_{\text {zero }}$ is the standard deviation of the $10 \mathrm{~Hz}$ zero-air signal during a $30 \mathrm{~min}$ measurement. Third, to calculate the volume mixing ratios, all compounds above the LOD were divided by the measured or assigned sensitivity. Compounds with signals below the LOD were disregarded from the further analysis (Table A1). For the concentration measurements 71 (out of 163) masses were above the LOD. In the case of the flux measurements, 57 out of 163 showed flux behavior and 36 (out of 57) masses were above the LOD. The rejected masses also include primary ions and impurities from the ion source (Table A1).

\subsubsection{Flux calculations}

Fluxes were derived using the eddy covariance (EC) method. In EC, the flux is calculated using a discretized covariance:

$\overline{w^{\prime} c^{\prime}}=\frac{1}{n} \sum_{i=1}^{n} w^{\prime}(i) c^{\prime}(i+\lambda / \Delta t)$,

where $w^{\prime}$ and $c^{\prime}$ are high-frequency fluctuations of vertical wind and concentration, respectively, $i$ the number of the measurement, $n$ is the sum of all measurements during the flux averaging time ( $30 \mathrm{~min}$ in this study), $\Delta t$ is the sampling interval $(0.1 \mathrm{~s})$ and $\lambda$ is the lag time caused by the sampling tubes (e.g., Kaimal and Finnigan, 1994).

In this study, vertical wind and VOC concentrations were both recorded at $10 \mathrm{~Hz}$ frequency. The flux calculation procedure was as follows.

First, the wind vector was 2-D rotated using the method described by Kaimal and Finnigan (1994). If the vertical rotation was more than $5^{\circ}$, the period was flagged and after the "compound with exchange" detection rejected from further analysis. Data which were measured during periods when the wind was coming through the tower was not filtered out (discussed in Acton et al., 2016).
The linear trend was removed from the concentrations while block averaging was used for the vertical wind measurements.

Next, cross covariance functions (CCFs) were calculated between the vertical wind and each of the volume mixing ratios for every $30 \mathrm{~min}$ measurement period. The lag time and compounds for which the flux was deemed detectable were identified with two different methods (Table 1), which are termed the "manual method" (Taipale et al., 2010) and the "automated method" (Park et al., 2013).

For the manual method the lag time was determined for each 30 min periods and compounds individually by maximizing the smoothed CCF from a lag time window of $0-5 \mathrm{~s}$ (Taipale et al., 2010). The smoothing of the CCF decreases possible flux overestimation caused by noise when using the maximum covariance method (Taipale et al., 2010; Langford et al., 2015). In the next step, compounds with detectable flux were identified by checking the CCFs manually for each individual compound and for several different $30 \mathrm{~min}$ periods. The total number of manually identified CCFs was well over 1000. Compounds for which a clear CCF maximum was found were used for the further flux calculations.

For the automated method, such as in Park et al. (2013), a constant lag time $(2.6 \mathrm{~s})$ was used for all compounds and all $30 \mathrm{~min}$ measurement points. This avoids overestimation in the flux, which can happen if the maximizing method is used for flux values close to the detection limit (Langford et al., 2015). This lag time used here was calculated from the averaged absolute CCF of isoprene, which exhibits a clear maximum. The individual $30 \mathrm{~min}$ lag times from the selected time window were also calculated to confirm that the lag time did not shift during the campaign. To identify the compounds with detectable flux, an automated flux searching routine was used. First, absolute CCFs for each compound were calculated using daytime values from 10:00 to 16:00 (CET), i.e., when good conditions for turbulence and high flux are present (see Fig. A5; Park et al., 2013). Next, the absolute values of the $30 \mathrm{~min}$ CCFs in this time window were averaged over the entire measurement period (Figs. A6 to A9). From this averaged $\mathrm{CCF}$, the routine automatically calculated the flux (at $2.6 \mathrm{~s}$ lag time), the average noise and the standard deviation of the noise $\left(\sigma_{\text {noise }}\right)$. The mean and standard deviation of the noise were determined from areas at the left and right border of the CCF spectra (Fig. A6 to A9). Finally, the mean noise was subtracted from the flux and then divided by $\sigma_{\text {noise }}$. For ratios $>3$ the respective compound was used for the further flux calculations.

The final flux values were calculated for each method from the original (not smoothed or absolute) $30 \mathrm{~min}$ CCFs by using the respective lag time and compound. The fluxes of both methods were then filtered using the stationarity criteria introduced by Foken and Wichura (1996): every 30 min period was divided into six 5 min subperiods and VOC fluxes were calculated for each $5 \mathrm{~min}$ period. If the flux values calculated using $5 \mathrm{~min}$ averages differed by more than $30 \%$, the period 
Table 1. Comparison between the manual and the automated method for calculating VOC fluxes. QC means quality criteria and 203 is the number of 30 min periods measured between 10:00 and 16:00.

\begin{tabular}{lll}
\hline Step & Manual & \multicolumn{1}{c}{ Automated } \\
\hline Detection of compounds & & with significant flux: \\
\hline detection of significant flux & manual & automated \\
number of checks per compound & $>20$ & 1 \\
amount of data used per check & $30 \mathrm{~min}$ & $203 \times 30 \mathrm{~min}$ \\
maximum of found masses in the literature* & $10-20$ & $\mathrm{ca.} 500$ \\
\hline Flux data calculation: & & \\
\hline lag time & variable $(0-5 \mathrm{~s})$ & constant $(2.6 \mathrm{~s})$ \\
wind vector rotation & $2-\mathrm{D}$ & $2-\mathrm{D}$ \\
QC: vertical rotation & $5^{\circ}$ & $5^{\circ}$ \\
QC: stationary criteria & $70 \%$ & $70 \%$ \\
\hline
\end{tabular}

* The number of compounds with exchange is dependent on many site-specific factors (e.g., ecosystem, meteorological characteristics).

was disregarded from further analysis. The stationarity criteria together with the $5^{\circ}$ tilt angle disregarded $43 \%$ of the data for each method.

For those compounds for which a flux could be detected, the uncertainty of the flux was calculated from the two $60 \mathrm{~s}$ time windows at the border of the CCFs for each 30 min flux value. The root mean square of each window was calculated and the results averaged. This follows the approach of Langford et al. (2015) and ensures that offsets (from zero) from the noise in the CCF tails are taken into account. For estimation of the uncertainty of the diurnal net flux, it was assumed that the errors of different flux values are independent, and the uncertainty can be calculated with the Gaussian propagation of error. The independence assumption is not fully correct, as fluxes from different compounds are derived using the same vertical wind data.

For the calculation of the diurnal $1 \mathrm{~h}$ flux data, all measurements which passed the quality checks were averaged. The daily average was then calculated by averaging the diurnal data. This ensures that periods which have fewer data points (due to quality criteria filtering, background or calibration measurements) do not get underrepresented in the daily average.

\subsubsection{Spectral corrections}

Due to the high-frequency attenuation and low-frequency cutoff, the measured EC flux underestimates the real flux (e.g., Moore, 1986; Horst, 1997). High-frequency attenuation is caused by the tubing, the sensor separation and the time response of the instrument itself, while low-frequency attenuation is caused by linear detrending or block averaging.

The effect of low-pass filtering can be quantified by the use of a transfer function. Formally the transfer function $H_{w c}$ can be written as

$H_{w c}(f)=\frac{C_{w c}(f)}{\overline{w^{\prime} c^{\prime}}} \times\left(\frac{C_{w \theta}(f)}{\overline{w^{\prime} \theta^{\prime}}}\right)^{-1}$,

where $C_{w c}$ and $C_{w \theta}$ are the cospectra of a scalar $c$ and $w$, and potential temperature $\theta$ and $w$, respectively. $\overline{w^{\prime} c^{\prime}}$ and $\overline{w^{\prime} \theta^{\prime}}$ are "unattenuated" turbulent fluxes of a scalar and temperature, respectively, and $f$ is the frequency. A commonly used approximation for the first-order transfer function is (Horst, 1997)

$H_{w c} \approx\left[1+(2 \pi \tau f)^{2}\right]^{-1}$,

where $\tau$ is a system response time.

In this study, we determined the high-frequency attenuation using a method described by Horst (1997). In the method the attenuation factor $\alpha$ is calculated by the equation

$\alpha=\frac{\overline{\left(w^{\prime} c^{\prime}\right)_{\mathrm{a}}}}{\overline{w^{\prime} c^{\prime}}}=\frac{1}{1+\left(\frac{2 \pi n_{\mathrm{m}} \tau \bar{u}}{z_{\mathrm{m}}-d}\right)^{\beta}}$,

where $z_{\mathrm{m}}$ is the measurement height $(32 \mathrm{~m}), d$ the zero displacement height $\left(d=2 / 3 \times z_{\mathrm{c}}\right.$, where $z_{\mathrm{c}}$ is the canopy height, $28 \mathrm{~m}), \bar{u}$ is the mean horizontal wind speed, $\overline{\left(w^{\prime} c^{\prime}\right)_{\mathrm{a}}}$ is the attenuated flux and $\overline{w^{\prime} c^{\prime}}$ is the real flux. For neutral and unstable stratification $\left(z_{\mathrm{m}}-d\right) / L \leq 0, \beta=7 / 8, n_{\mathrm{m}}=0.085$, and for stable stratification, $\left(z_{\mathrm{m}}-d\right) / L>0, \beta=1, n_{\mathrm{m}}=$ $2.0-1.915 /\left[1+0.5\left(z_{\mathrm{m}}-d\right) / L\right]$.

We selected daytime (10:00-16:00 CET wintertime), unstable $\left(\overline{w^{\prime} T^{\prime}}>0\right)$ periods, and calculated cospectra of temperature, isoprene and water clusters for every $30 \mathrm{~min}$ inter$\mathrm{val}$. Response times of isoprene and water clusters were then derived by using Eq. (10) and the median transfer functions (Eq. 9). After that, the flux losses were derived using the correction factor $\alpha^{-1}$ (Eq. 11) and the response time of the isoprene measurements, $\tau=1.1 \mathrm{~s}$ (Fig. 3). This value is similar 

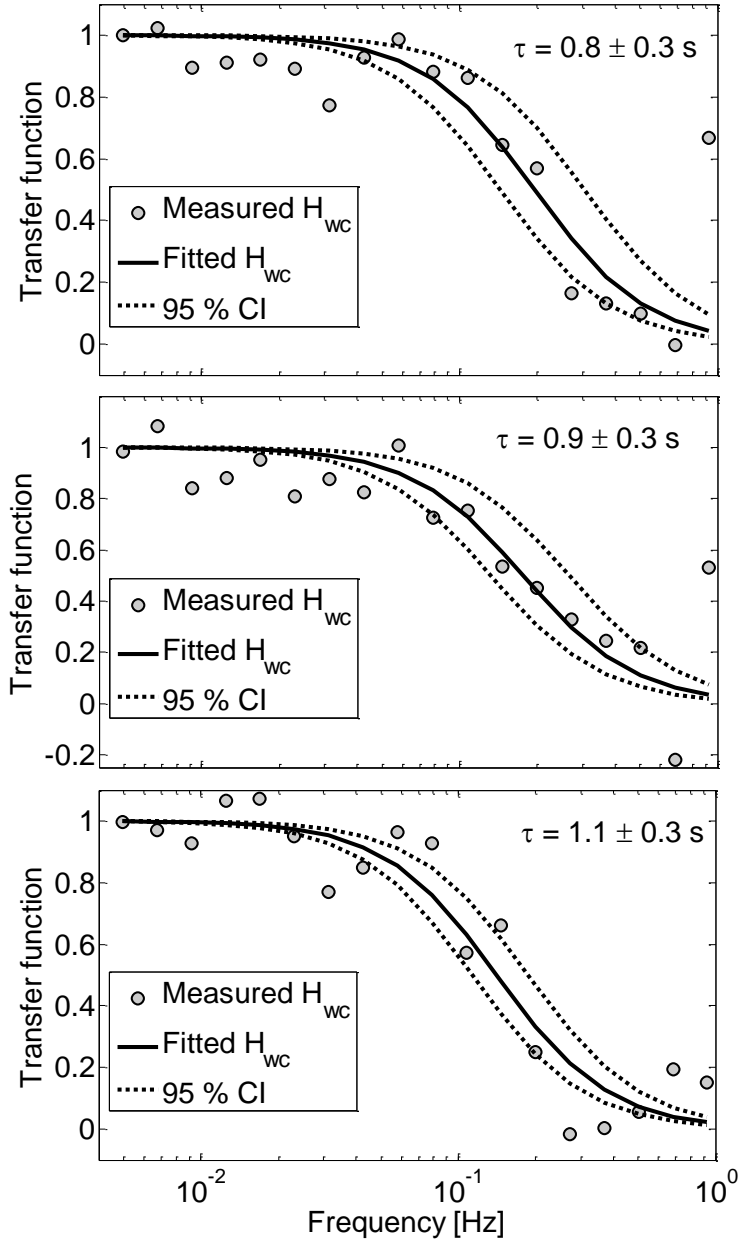

Figure 3. Transfer functions of $\mathrm{H}_{3} \mathrm{O}^{+} \mathrm{H}_{2} \mathrm{O}$ (37.0284 amu; top), $\mathrm{H}_{3} \mathrm{O}^{+}\left(\mathrm{H}_{2} \mathrm{O}\right)_{2}$ (55.039 amu; middle) and $\mathrm{C}_{5} \mathrm{H}_{8} \mathrm{H}^{+}(69.0699 \mathrm{amu}$; bottom). The circles are the measurements, the solid black line the fitted transfer function and the dashed lines are the $95 \%$ confidence intervals. The response time of the measurement system, $\tau$, was calculated by fitting Eq. (10) to the data.

to that obtained by Rantala et al. (2014), who utilized disjunct EC with a PTR-QMS. The correction factor $\alpha^{-1}$ was finally multiplied to each VOC flux value. During daytime, the factor was mostly less than $10 \%$, and during nighttime typically around $20 \%$, resulting in overall correction of the isoprene flux, dominated by daytime emission, of $11 \%$.

The value $\tau=1.1 \mathrm{~s}$ represents the response time of the whole system including the instrument and the inlet line. Therefore, the response time should be determined for each measurement setup individually as, for example, the length of the inlet line has an effect on the attenuation (Nordbo et al., 2013, 2014). The response time is also probably compound dependent because the attenuation of water vapor increases as a function of relative humidity (Mammarella et al., 2009). Thus, similar kind of behavior could be expected for water solvable compounds, such as methanol. In that sense, the high-frequency corrections should be taken as rough estimates.

\subsubsection{Flux loss due to chemical degradation}

The chemical degradation of different VOCs is dependent on their concentration, reaction rates and concentrations of oxidants $\left(\mathrm{O}_{3}, \mathrm{NO}_{3}, \mathrm{OH}\right)$. Therefore the proxy for $\mathrm{OH}$ concentration, $[\mathrm{OH}]_{\text {proxy }}$, was calculated according to Peräkylä et al. (2014) and Petäjä et al. (2009):

$[\mathrm{OH}]_{\text {proxy }}=5.62 \times 10^{5} \times \mathrm{UVB}^{0.62}$.

The calculated average midday concentration of the $[\mathrm{OH}]_{\text {proxy }}$ was $1 \times 10^{6} \# \mathrm{~cm}^{-3}$.

As the UVB radiation was not measured directly during the Bosco Fontana study, an upper limit calculation was made by using the tropospheric ultraviolet model 4.1 (TUV; Madronich, 1993; Madronich and Flocke, 1999). The model was used via http://cprm.acom.ucar.edu/Models/ TUV/Interactive_TUV, using the pseudo-spherical discrete ordinate four-stream radiation transfer model and an albedo of 0.1 . The $\mathrm{NO}_{3}$ concentration was calculated as described in Peräkylä et al. (2014) from the measured concentrations of $\mathrm{NO}_{2}$ and $\mathrm{O}_{3}$.

The influence of chemical degradation on the measured EC fluxes depends on the relative magnitude of the chemical lifetime of the measured compound and its transport time. The transport time is the time the compound needs to get from its emission point to the actual measure point, and it can be characterized by turbulent mixing timescale. The effect is often assessed using the Damköhler number (Damköhler, 1940), which is the ratio of the mixing timescale to the chemical lifetime. The smaller the Damköhler number is, the less influence the chemical degradation has on the flux. However, since both the transport time and the chemical lifetime are height dependent, a more accurate assessment of the loss is achieved by calculating the ratio of the flux at the measurement height $(F)$ to the true surface exchange $(E)$, e.g., using a stochastic Lagrangian transport model (Rinne et al., 2012). In Bosco Fontana, the $F / E$ for isoprene was 0.950.97 , indicating that the measured fluxes are between 3 and $5 \%$ lower than the emission due to the chemical degradation. For the monoterpenes (we used $\alpha$-pinene), which have the lowest $F / E$ ratio (shortest lifetime) of the measured compounds, the $F / E$ was between 0.8 and 0.95 . No corrections for the chemical degradation have been made in this study.

\subsection{Modeled MVK/MACR production}

After having quantified the average fraction of the isoprene flux lost between point of emission and the measurement height, this section uses an alternative method to quantify the fraction of the observed MVK/MACR flux that is expected to be produced by the atmospheric oxidation of isoprene below 


\begin{tabular}{|lll|l|l|}
\hline $\mathrm{C}_{5} \mathrm{H}_{9}^{+}$ & (Isoprene) & $\mathrm{C}_{1} \mathrm{H}_{5} \mathrm{O}_{1}^{+}$(Methanol) & $\mathrm{C}_{3} \mathrm{H}_{7} \mathrm{O}_{1}^{+}$(Acetone) & $\mathrm{C}_{4} \mathrm{H}_{7} \mathrm{O}_{1}^{+}$(MVK \& MACR) \\
$\mathrm{C}_{2} \mathrm{H}_{5} \mathrm{O}_{1}^{+}$(Acetaldehyde) & $\mathrm{C}_{10} \mathrm{H}_{17}^{+}$(Monoterpenes) & $\mathrm{C}_{2} \mathrm{H}_{5} \mathrm{O}_{2}^{+}$(Acetic acid) & $\mathrm{C}_{3} \mathrm{H}_{5} \mathrm{O}_{1}^{+}$(Acrolein) \\
$\mathrm{C}_{3} \mathrm{H}_{7} \mathrm{O}_{2}^{+}$(Hydroxyacetone) & $\mathrm{C}_{6} \mathrm{H}_{11}^{+} \quad\left(\mathrm{C}_{6}\right.$ GLV F) & $\mathrm{C}_{5} \mathrm{H}_{9} \mathrm{O}_{1}^{+}$(Pentanal) & $\mathrm{C}_{5} \mathrm{H}_{9} \mathrm{O}_{2}^{+}$(?) \\
\hline Other & (18) & & & \\
\hline
\end{tabular}
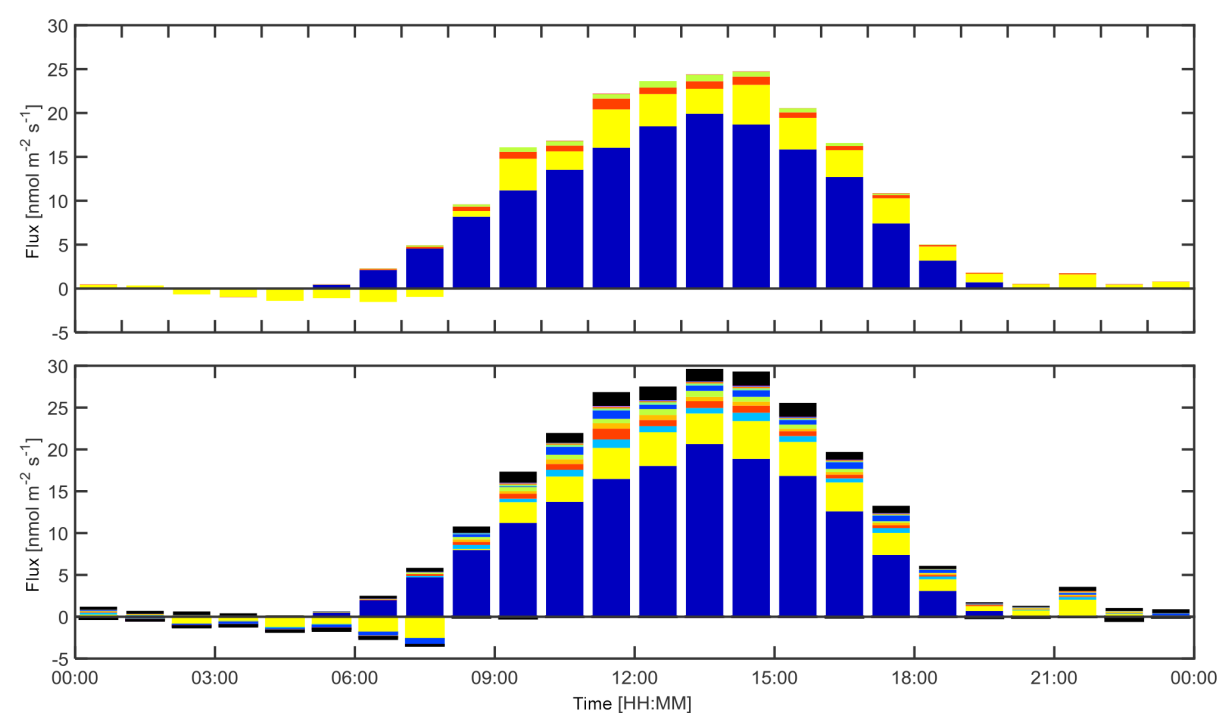

Figure 4. Diurnal flux plot of the manual method (top panel) and the automated method (bottom panel). For the automated method, the $10 \sigma_{\text {noise }}$ compounds are plotted individually, while the remaining 18 compounds, which passed the $3 \sigma_{\text {noise }}$ threshold (see Table A1), are summed up and plotted as "other". All individual flux compounds are listed in Table 2.

the measurement height. This is done by integration of the chemical kinetic equation.

The chemical destruction of isoprene $F_{Q}$, in an air column below the measurement level can be calculated as

$F_{Q}=\int_{0}^{z_{\mathrm{m}}} \sum_{i} k_{i}\left[R_{i}\right]\left[\mathrm{C}_{5} \mathrm{H}_{8}\right] \mathrm{d} z$,

where $k_{i}$ is the rate constant, $\left[R_{i}\right]$ is the concentration of reactant $i$, and $\left[\mathrm{C}_{5} \mathrm{H}_{8}\right]$ is the concentration of isoprene. The integration is done from surface to the measurement height $z_{\mathrm{m}}$. Even though $\left[\mathrm{C}_{5} \mathrm{H}_{8}\right]$ and $\left[R_{i}\right]$ are height dependent (Andronache et al., 1994; Hens et al., 2014), we assumed constant reactant and isoprene concentrations for the integration range as no profiles were measured in order to get an order of magnitude estimate. The chemical destruction was estimated for two ranges: from the ground level 0 to the measurement height and from the notional height $\left(d+z_{0}\right)$ to the measurement height. The angle brackets, \langle\rangle , indicate that the values are constant:

$Q=\mathrm{k}_{\mathrm{i}}\left\langle\left[R_{i}\right]\right\rangle\left\langle\left[\mathrm{C}_{5} \mathrm{H}_{8}\right]\right\rangle z_{\mathrm{m}}$,

$Q=\mathrm{k}_{\mathrm{i}}\left\langle\left[R_{i}\right]\right\rangle\left\langle\left[\mathrm{C}_{5} \mathrm{H}_{8}\right]\right\rangle\left(\mathrm{z}_{\mathrm{m}}-d-\mathrm{z}_{0}\right)$.

Due to the smaller reaction rates and the lower MVK/MACR concentration, we did not calculate the chemical destruction of MVK/MACR.

In order to estimate the yield of MVK and MACR from isoprene, we selected the isoprene chemistry mech- anism from the Master Chemical Mechanism (MCM) v3.2 (Jenkin et al., 1997; Saunders et al., 2003), available via http://mcm.leeds.ac.uk/MCM/. The concentrations of MVK and MACR were calculated using the Kinetic PreProcessor (Damian et al., 2002) coupled to the box model MALTE-BOX (Boy et al., 2013). The simulation was executed using an initial concentration of isoprene $\left(5.33 \times 10^{10} \# \mathrm{~cm}^{-3}\right.$; measured) and constant concentrations of $\mathrm{OH}\left(1 \times 10^{6} \mathrm{\#} \mathrm{cm}^{-3}\right.$; calculated $), \mathrm{O}_{3}\left(2 \times 10^{12} \mathrm{\#} \mathrm{cm}^{-3}\right.$; measured $)$, NO $\left(3.5 \times 10^{9} \mathrm{\#} \mathrm{cm}^{-3} ;\right.$ measured $), \mathrm{NO}_{2}$ $\left(8 \times 10^{10} \mathrm{\#} \mathrm{cm}^{-3}\right.$; measured $), \mathrm{SO}_{2}\left(1 \times 10^{9} \mathrm{\#} \mathrm{cm}^{-3}\right.$; estimated $)$ and $\mathrm{CO}\left(3.5 \times 10^{12} \mathrm{\#} \mathrm{cm}^{-3}\right.$; estimated $)$. The temperature was further kept constant to a value of $303 \mathrm{~K}$, while the start of the simulation was assumed to be at noon (local time). By dividing the initial concentration of isoprene by the summed maximum concentration of MVK and MACR, we estimate that the summed yield of MVK and MACR from oxidized isoprene is 0.35. This factor accounts for oxidation losses of MVK and MACR. A sensitivity test showed that the MVK/MACR yield response to a change in temperature and $\mathrm{SO}_{2}$ concentration is minor. For $\mathrm{CO}$, a concentration change to $5 \times 10^{13} \mathrm{\#} \mathrm{cm}^{-3}$ results in a $5 \%$ lower yield. Due to the high $\mathrm{NO}_{x}$ concentration in Bosco Fontana, the reaction way via isoprene hydroxy hydroperoxides (ISOPOOH) does not form MVK/MACR. 


\section{Results and discussion}

\subsection{Comparison of procedures to identify detectable fluxes}

In the following the data from 22 days of flux measurements are used by different analysis routines, and the results are compared. Negative fluxes are called downward fluxes, as it is not possible to differentiate between deposition and other sink terms such as chemical losses below the measurement height. The positive fluxes are called upward fluxes. The diurnal cycles of the fluxes derived by the manual method and automated method (evaluated using a $10 \sigma_{\text {noise }}$ threshold) are shown in Fig. 4. The signal of the remaining masses with detectable flux (between 3 and $10 \sigma_{\text {noise }}$ ) quantified by the automated method is summed up and plotted as "other". The $24 \mathrm{~h}$ average fluxes of the different compounds and different methods are shown in Table 2.

The manual method identified the lower number of compounds (5), accounting for the lower total upward flux $\left(8.53 \mathrm{nmol} \mathrm{m}^{-2} \mathrm{~s}^{-1}\right)$ and also the lower total downward flux $\left(-0.28 \mathrm{nmol} \mathrm{m}^{-2} \mathrm{~s}^{-1}\right)$. The only compound with a flux that was deemed quantifiable by the manual method but not by the automated method with $10 \sigma_{\text {noise }}$ was $\mathrm{C}_{5} \mathrm{H}_{9} \mathrm{O}_{2}^{+}$(protonated), which contributed $1.2 \%$ to the total downward flux and $0.1 \%$ to the total upward flux.

The automated method with a $10 \sigma_{\text {noise }}$ threshold found 11 compounds with detectable flux and derived a total upward flux of $9.6 \mathrm{nmol} \mathrm{m}^{-2} \mathrm{~s}^{-1}$. The downward flux reached $-0.48 \mathrm{nmol} \mathrm{m}^{-2} \mathrm{~s}^{-1}$. If the $3 \sigma_{\text {noise }}$ threshold was used, the number of compounds with detectable flux increased to 29 but the total upward flux was nearly the same $\left(10.4 \mathrm{nmol} \mathrm{m}^{-2} \mathrm{~s}^{-1}\right)$, while the downward flux increased to $-0.58 \mathrm{nmol} \mathrm{m}^{-2} \mathrm{~s}^{-1}$. The main additional masses with detectable flux were acetone, acetaldehyde and acetic acid. As discussed in Sect. 2.3.2, fragments, water clusters and isotopes identified during calibrations were removed from the data. The disregarded masses are shown in Table A1.

Figure 5 shows the diurnal variation of the net flux for the two approaches. The maximum difference in the hourly net flux between a $3 \sigma_{\text {noise }}$ threshold and a $10 \sigma_{\text {noise }}$ threshold was less than $1.3 \mathrm{nmol} \mathrm{m}^{-2} \mathrm{~s}^{-1}$ and the daily average differed less than $0.5 \mathrm{nmol} \mathrm{m}^{-2} \mathrm{~s}^{-1}$. The major difference lies in the number of masses that are found to contribute to the total VOC flux: 29 ( $\left.3 \sigma_{\text {noise }}\right), 22$ ( $\left.4 \sigma_{\text {noise }}\right), 22\left(5 \sigma_{\text {noise }}\right), 19\left(6 \sigma_{\text {noise }}\right), 15$ $\left(7 \sigma_{\text {noise }}\right), 14\left(8 \sigma_{\text {noise }}\right), 12\left(9 \sigma_{\text {noise }}\right)$, and $11\left(10 \sigma_{\text {noise }}\right)$.

The manual method is rather labor intensive, because the CCF must be checked for many different mass peaks ( $>150$, depending on the environment where the measurements are recorded) for several different times of the campaign (overall well over $1000 \mathrm{CCFs}$ ). Another weakness is that the definition of a "clear maxima" is not objective and depends on the person who is working with the data. A positive aspect is that, during the manual evaluation of the data, possible problems or analysis faults can be detected more easily.

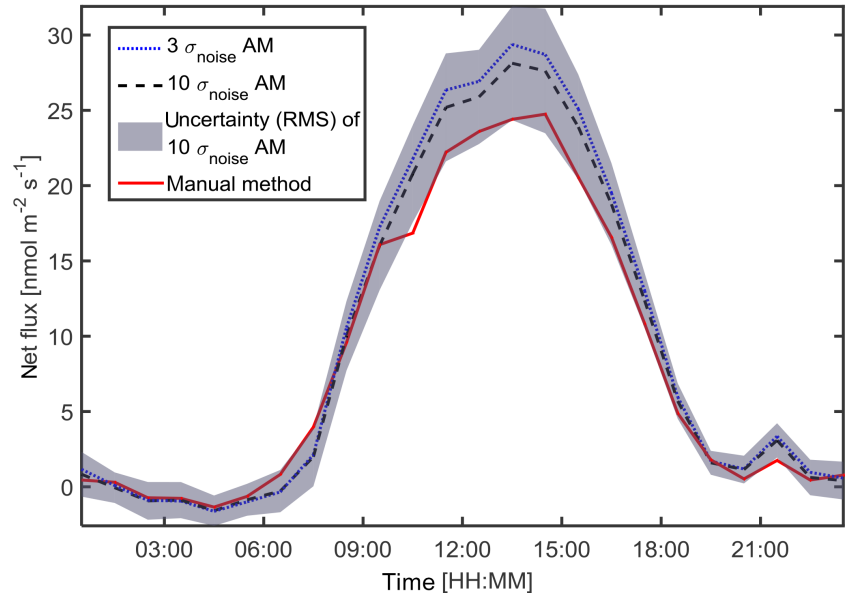

Figure 5. Diurnal net flux of the automated method (AM) with 3 and $10 \sigma_{\text {noise }}$ threshold for the flux calculation and the manual method. The uncertainty (root mean square) was calculated for the automated method with $10 \sigma_{\text {noise }}$. The time is in CET wintertime.

Compared to the manual method, the automated method gives a fast and objective result and the quality of the fluxes can be selected by the different $\sigma_{\text {noise }}$ criteria. However, using the absolute value of the signal changes the mean value of it and thereby reduces the variation and the standard deviation of the signal (see Figs. A4 and A5). For example, the standard deviation of the averaged absolute CCF was $21 \%$ smaller than the standard deviation of the averaged CCF for acetone. This effect can be seen in the difference of the mean noise in Figs. A4 and A5. The higher mean noise corrects for the lower $\sigma_{\text {noise }}$, but it is constant for different $\sigma_{\text {noise }}$ criteria.

In the remainder of paper, all mentioned flux values were calculated using the automated method with $3 \sigma_{\text {noise }}$ threshold and the time zone used was CET wintertime (UTC $+1 \mathrm{~h}$ ).

\subsection{Comparison to other studies}

Comparing VOC concentration and especially fluxes from different locations (and/or times) is challenging as the results are dependent on ecosystem type, meteorology and the surroundings of the measurement site, as well as the instrumental setup (e.g., inlet length).

The most obvious difference compared to the study by Park et al. (2013) was the number of masses showing fluxes. Park et al. (2013) found 494 (out of 664 masses) showed flux above the orange grove, whereas in this study only 29 (out of 163 masses) were found to have flux. While in both studies the results depended heavily on the $\sigma_{\text {noise }}$ threshold, in this study the differences were much more subtle. In the study by Park et al. (2013), the number of ions with flux differed by 2 orders of magnitude. In our study, compounds which fulfilled the three $3 \sigma_{\text {noise }}$ criteria, but not the $10 \sigma_{\text {noise }}$ criteria, contributed $16 \%$ to the total downward flux, and $7 \%$ to the total upward flux. However, the amount of compounds fil- 
Table 2. Downward flux (df) and upward flux (uf) calculated with different methods. The individual compounds listed under automated are for a $10 \sigma_{\text {noise }}$ threshold, the remaining compounds (between 3 and $10 \sigma_{\text {noise }}$ ) are summed up under "other".

\begin{tabular}{|c|c|c|c|c|c|c|}
\hline \multirow{3}{*}{$\begin{array}{l}\text { Possible } \\
\text { compound }\end{array}$} & \multirow{3}{*}{$\begin{array}{r}\text { Mass } \\
\text { Th }\end{array}$} & \multirow{3}{*}{$\begin{array}{l}\text { Elemental } \\
\text { composition }\end{array}$} & \multicolumn{2}{|c|}{ Manual method } & \multicolumn{2}{|c|}{ Automated method } \\
\hline & & & \multicolumn{4}{|c|}{$\%$ of total downward flux (df) or upward flux (uf) } \\
\hline & & & $\mathrm{df}(-0.28)^{1}$ & uf $(8.5)^{1}$ & df $(-0.58)^{1}$ & uf $(10.4)^{1}$ \\
\hline isoprene $e^{c}$ & 69.0699 & $\mathrm{C}_{5} \mathrm{H}_{9}^{+}$ & 0.2 & 75.0 & 0.0 & 62.4 \\
\hline methanol ${ }^{\mathrm{c}}$ & 33.0335 & $\mathrm{C}_{1} \mathrm{H}_{5} \mathrm{O}_{1}^{+}$ & 97.3 & 18.4 & 63.2 & 14.8 \\
\hline acetone $^{\mathrm{c}}$ & 59.0491 & $\mathrm{C}_{3} \mathrm{H}_{7} \mathrm{O}_{1}^{+}$ & & & 1.7 & 3.3 \\
\hline MVK/MACR ${ }^{c}$ & 71.0491 & $\mathrm{C}_{4} \mathrm{H}_{7} \mathrm{O}_{1}^{+}$ & 1.1 & 3.9 & 0.8 & 3.0 \\
\hline acetaldehyde ${ }^{c}$ & 45.0335 & $\mathrm{C}_{2} \mathrm{H}_{5} \mathrm{O}_{1}^{+}$ & & & 0.2 & 2.2 \\
\hline monoterpenes $^{\mathrm{c}}$ & 137.133 & $\mathrm{C}_{10} \mathrm{H}_{17}^{+}$ & 0.2 & 2.6 & 0.1 & 2.1 \\
\hline acetic acid ${ }^{2}$ & 61.0284 & $\mathrm{C}_{2} \mathrm{H}_{5} \mathrm{O}_{2}^{+}$ & & & 16.7 & 3.0 \\
\hline acrolein $^{\mathrm{c}}$ & 57.0335 & $\mathrm{C}_{3} \mathrm{H}_{5} \mathrm{O}_{1}^{+}$ & & & 0.3 & 0.8 \\
\hline hydroxyacetone & 75.0441 & $\mathrm{C}_{3} \mathrm{H}_{7} \mathrm{O}_{2}^{+}$ & & & 0.8 & 0.7 \\
\hline $\mathrm{C}_{8} \mathrm{GLV}^{3}$ & 83.0855 & $\mathrm{C}_{6} \mathrm{H}_{11}^{+}$ & & & 0.0 & 0.3 \\
\hline pentanal & 85.0648 & $\mathrm{C}_{5} \mathrm{H}_{9} \mathrm{O}_{1}^{+}$ & & & 0.1 & 0.2 \\
\hline unknown & 101.0597 & $\mathrm{C}_{5} \mathrm{H}_{9} \mathrm{O}_{2}^{+}$ & 1.2 & 0.1 & 0 & 0 \\
\hline other (18) & & & & & 16.2 & 7.0 \\
\hline
\end{tabular}

${ }^{1}$ shows the total uf or $\mathrm{df}$ in $n m o l \mathrm{~m}^{-2} \mathrm{~s}^{-1},{ }^{2}$ acetic acid was corrected for fragmentation (see Sect. 2.3.2); ${ }^{3} \mathrm{C}_{6}$ green leaf volatiles (GLV) are calculated via the fragment $\mathrm{C}_{6} \mathrm{H}_{11}^{+}$; the fragmentation pattern and the sensitivity of hexanal were used.

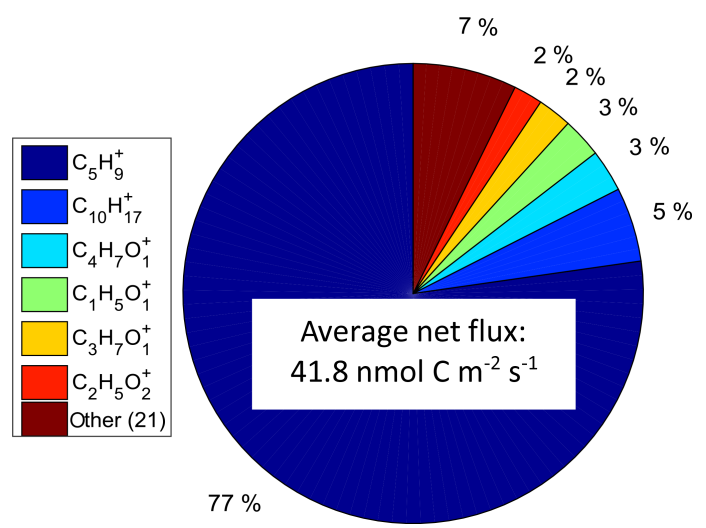

Figure 6. Average net flux of the major carbon emitters. Two masses were disregarded, as no matching elemental composition was found.

tered by the $\sigma_{\text {noise }}$ criteria changed from 29 ( $\left.3 \sigma_{\text {noise }}\right)$ to 11 $\left(10 \sigma_{\text {noise }}\right)$.

A comparison between the measured fluxes from this study and their values at the orange grove (Park et al., 2013) can be found in Table A2. The major difference was the large upward flux of isoprene measured in Bosco Fontana, which contributed $65 \%$ to the total net flux of $9.8 \mathrm{nmol} \mathrm{m}^{-2} \mathrm{~s}^{-1}$. This net flux of all compounds is twice as much as at the orange orchard. All the major compounds ( $\left.>8 \sigma_{\text {noise }}\right)$ from the orange grove, except para-cymene, were also present in Bosco Fontana. Six of the remaining major compounds ( $>8 \sigma_{\text {noise }}$ ) of the orange grove had net fluxes which agree within $50 \%$ with the measured net fluxes in this study (isoprene and MVK/MACR being the exception). The net carbon exchange in Bosco Fontana is shown in Fig. 6. Isoprene is the dominating compound and contributed $77 \%$ to the carbon net flux, followed by the monoterpenes (5\%), MVK/MACR $(3 \%)$, methanol (3\%), acetone $(2 \%)$ and acetic acid $(2 \%)$. Overall, the measured and identified compounds had a net carbon flux of $41.8 \mathrm{nmol} \mathrm{C} \mathrm{m}^{-2} \mathrm{~s}^{-1}$. Two masses were not taken into account, as their elemental composition could not be determined (Table A2).

This net flux of carbon at Bosco Fontana is about 4 times higher than the values published by Park et al. (2013). If the net carbon emission of the measured compounds is compared to the net uptake of $\mathrm{CO}_{2}$ during the measurement period $\left(2423 \mathrm{nmol} \mathrm{C} \mathrm{m}^{-2} \mathrm{~s}^{-1}\right)$ the influence is less than $2 \%$ in Bosco Fontana. The daily average value of $\mathrm{CO}_{2}$ gas exchange was $-9.2 \mathrm{~g} \mathrm{C} \mathrm{m}^{-2}$, similar to what observed by Wilson and Baldocchi (2001) over a mixed deciduous forest.

\subsection{Emission of terpenoids}

The most abundant compound emitted by the Bosco Fontana forest was isoprene (protonated formula: $\mathrm{C}_{5} \mathrm{H}_{9}^{+}$), comprising over $60 \%$ of the measured total upward flux. It had a clear diurnal cycle which follows the radiation. The maximum upward flux (diurnal) at $20.6 \mathrm{nmol} \mathrm{m}^{-2} \mathrm{~s}^{-1}$ occurred just after midday. Figure $7 \mathrm{~b}$ shows the wind rose for the isoprene flux. There are more isoprene emitting plants to the west of the site, indicated by the highest fluxes coming from this direction. Indeed, Acton et al. (2016) found that taking the contri- 
(a)
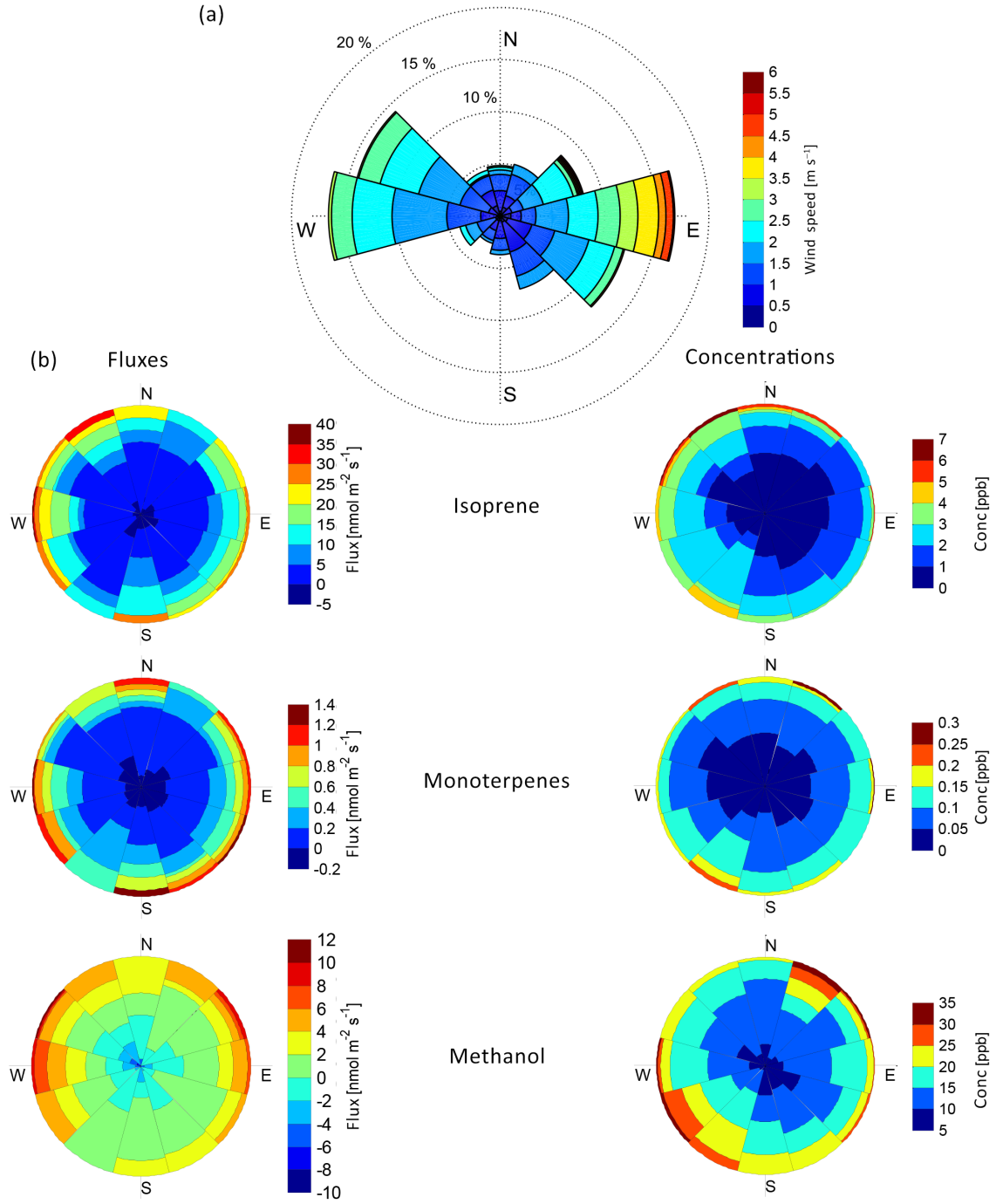

Monoterpenes

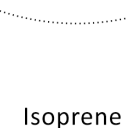

Methanol

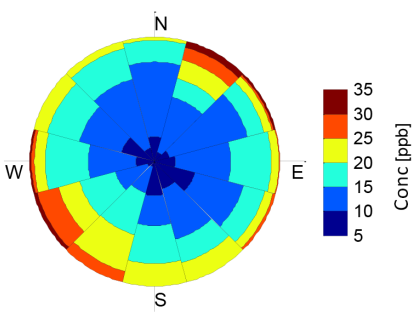

Figure 7. (a) Wind rose of the wind speed. The percentages describe how often the wind came from the selected wind direction. (b) Unscaled wind roses for fluxes (left) and concentrations (right) of isoprene (top), monoterpenes (middle), and methanol (bottom).

bution of the strong emitters in this wind sector into account improved the correlation between predicted and measured isoprene fluxes. Similar behavior can be seen from the wind rose of the isoprene concentrations, although the extent of the forest is smaller towards southwest, providing less opportunity for isoprene to accumulate during advection. From 21:00 to $05: 00$ the upward flux stayed below $0.1 \mathrm{nmol} \mathrm{m}^{-2} \mathrm{~s}^{-1}$. The main sink of isoprene is oxidation due to reactions with $\mathrm{OH}$ during daytime. The calculated isoprene lifetime for daytime conditions in Bosco Fontana was $2.2 \mathrm{~h}$.

The fast oxidation, together with the relatively small extent of the woodland in a mixed agricultural landscape with relatively low isoprene emissions, explains why the diurnal concentration maximum of isoprene was only $2.8 \mathrm{ppb}$, even though the isoprene upward flux was dominating all other measured VOCs. Its daily average concentration was $1.3 \mathrm{ppb}$. The emission factors of isoprene and monoterpenes in Bosco
Fontana, as well as the as the relative importance of pool and de novo emissions, are discussed in Acton et al. (2016). Isoprene's major source globally is forests (Guenther et al., 1995); oaks are known for being isoprene emitters (Rasmussen, 1970) and dominate European isoprene emissions. Potosnak et al. (2014) measured a maximum isoprene emission of $217 \mathrm{nmol} \mathrm{m}^{-2} \mathrm{~s}^{-1}$ over an oak-dominated temperate forest in central Missouri.

2-Methyl-3-buten-2-ol (MBO) can dehydrate in the proton transfer reaction and form isoprene (Fall et al., 2001; de Gouw and Warneke, 2006; Kaser et al., 2013). The influence on the isoprene signal depends on the MBO concentration and the settings of the PTR-ToF. The contribution of MBO to the isoprene signal in Bosco Fontana should be minor, as the major tree species are known to be isoprene or monoterpene emitters (König et al., 1995; Harley et al., 1999; Rosenstiel et al., 2002) as confirmed by the more specific leaf-level mea- 
surements of Acton et al. (2016). However, a possible MBO source could be the understory of the forest.

In Bosco Fontana, monoterpenes have been the seventh most emitted "compound group" with a maximum diurnal upward flux of $0.7 \mathrm{nmol} \mathrm{m}^{-2} \mathrm{~s}^{-1}$. Leaf-level measurements at Bosco Fontana presented by Acton et al. (2016) found the largest monoterpene emissions to be limonene originating from Carpinus betulus and Corylus avellana and to some extent Cornus sanguinea, augmented with smaller emissions of $\alpha$-pinene from $Q$. robur and Acer campestre, and $\beta$-pinene from $A$. campestre and $C$. betulus. Figure $7 \mathrm{~b}$ shows the normalized wind rose of the monoterpenes upward flux (independent of the frequency of wind directions). The measurement site is very homogeneous, as no wind direction dependency on the monoterpenes flux was detected. This also holds for the monoterpene concentrations.

\subsection{MVK/MACR and their sources}

MVK and MACR have the same elemental composition (protonated formula: $\mathrm{C}_{4} \mathrm{H}_{7} \mathrm{O}^{+}$) and cannot be separated with our instrument settings. In Bosco Fontana, $3 \%$ of the total upward VOC flux was due to MVK/MACR, which are both oxidation products of isoprene. To give an estimate of how much of the MVK/MACR flux is likely to have originated from atmospheric oxidation of isoprene below the measurement level $z_{\mathrm{m}}$, we used two methods to estimate the flux divergence. The oxidation of isoprene is dominated by the reaction with the $\mathrm{OH}$ radical. The daytime maximum flux of isoprene oxidation products between ground level and measurement height were around $0.61 \mathrm{nmol} \mathrm{m}^{-2} \mathrm{~s}^{-1}$ (Eq. 14) and $0.24 \mathrm{nmol} \mathrm{m}^{-2} \mathrm{~s}^{-1}$ (Eq. 15) if the lower limit is the notional height. However, the result of the integration (Eq. 13) varies considerably depending on the integration domain and the assumed profiles.

Another approach to estimate the chemical degradation is to use the look-up tables for flux-to-surface-exchange $(F / E)$ ratios created using a stochastic Lagrangian transport model by Rinne et al. (2012). For the $F / E$ ratio we use typical daytime values of friction velocity and chemical lifetime of isoprene. Depending on the assumed oxidant profile and leaf area index, $F / E$ ratios ranged between 0.97 and 0.95 . Multiplying the isoprene upward flux by the $F / E$ ratio leads to the oxidation fluxes between 0.6 and $1.0 \mathrm{nmol} \mathrm{m}^{-2} \mathrm{~s}^{-1}$.

According to our calculations (Sect. 2.4), $35 \%$ of the oxidized isoprene molecules will create MVK or MACR molecules (for midday conditions). The scatter plot between the measured MVK/MACR flux and the calculated source of MVK/MACR by the oxidation of isoprene below the measurement height (Fig. 8) shows a correlation coefficient of 0.81 . This correlation, however, does not necessarily imply causality. The biogenic VOC emissions and concentrations, as well as the concentration of $\mathrm{OH}$ radicals, are light dependent, which may lead to correlations where causality does not exist.

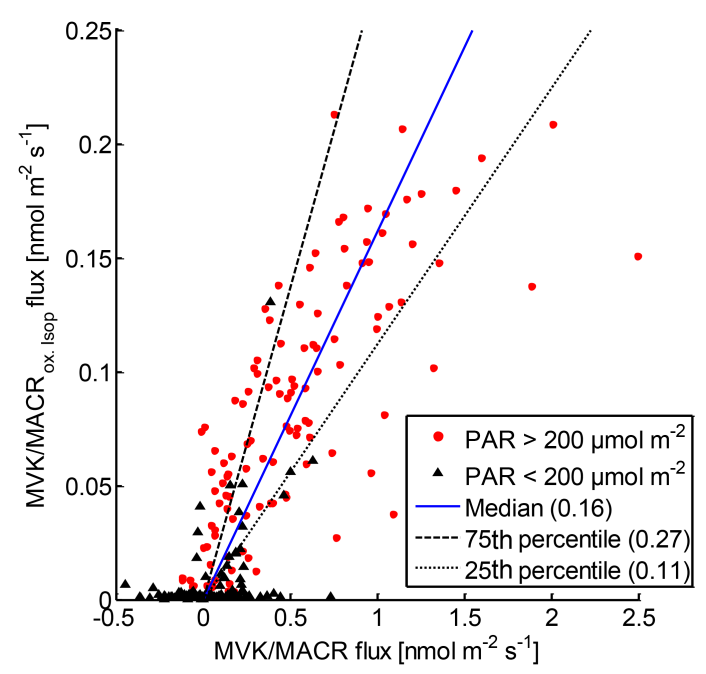

Figure 8. Scatter plot of the calculated MVK/MACR flux from oxidation of isoprene and the observed MVK/MACR flux. The correlation factor for the data is 0.81 . The $1 \mathrm{~h}$ data are separated to day and night values by a $200 \mu \mathrm{mol} \mathrm{m}^{-2}$ photosynthetically active radiation (PAR) threshold. The $\frac{y}{x}$ ratios of the daytime data have been calculated to determine the median and the 25 th and 75 th percentiles. The MVK/MACR flux from oxidation of isoprene was calculated using Eq. (14).

The hourly data in the plot were separated into day and night by using a $200 \mu \mathrm{mol} \mathrm{m} \mathrm{m}^{-2} \mathrm{~s}^{-1}$ photosynthetically active radiation threshold. Then the $\frac{y}{x}$ ratios of the daytime data were used to calculate the median and percentile ratios. The influence of the oxidation of isoprene to the measured MVK/MACR flux was estimated from the 25th and 75th percentiles ratios. If Eq. (14) was used to calculate this influence, the oxidation products of isoprene vary between 10 and $30 \%$ of the MVK/MACR flux. If Eq. (15) was used, the contribution of isoprene to the MVK/MACR flux varied between 4 and $10 \%$.

Comparing the results of the $F / E$ calculations with the maximum diurnal MVK/MACR flux of $1.3 \mathrm{nmol} \mathrm{m}^{-2} \mathrm{~s}^{-1}$ suggested that a contribution of 16 to $27 \%$ of the MVK/MACR flux may originate from atmospheric chemistry. Overall the oxidation of isoprene may have an important influence (4 to $30 \%$ ) on the MVK/MACR flux, but it fails to explain it fully.

Fluxes can also originate from direct MVK/MACR emissions from the plant as shown by Jardine et al. (2012). Other studies have shown also minor (Fares et al., 2015) or negligible (Karl et al., 2009, 2010) emission of MVK/MACR; however, in these studies there was a net uptake to the leaf. Part of the MVK/MACR concentration and fluxes may also be misattributed fragments from higher oxygenated hydrocarbons (Liu et al., 2013; Rivera-Rios et al., 2014). MVK and MACR have also been found to be formed from the decomposition of hydroxyl hydroperoxides (ISOPOOH) in the PTR-MS inlet. However, the ISOPOOH precursor ISOPO2 will be effec- 
tively quenched by NO. Therefore the ISOPOOH concentration in polluted environments such as the Po Valley would be expected to be very low, and consequently this artifact can be ruled out at this location. Additionally, an existing interference by ISOPOOH would most likely lead to unrealistic MVK/MACR deposition, due to an expected downward flux of peroxides (Nguyen et al., 2015).

In general, a comprehensive theory of MVK/MACR emission and deposition is lacking, while in some environments (especially in the tropics) MVK/MACR is found to deposit fast, approaching the maximum rate permitted by turbulence (i.e., with a small canopy uptake resistance; cf. Misztal et al., 2011, and references therein), while in other environments, like at Bosco Fontana, upward fluxes are observed.

\subsection{Emission of oxygenated VOCs}

The second-most emitted compound was methanol (protonated formula: $\mathrm{CH}_{5} \mathrm{O}^{+}$), whose upward flux started at 08:00, later compared with the remaining VOCs. It contributed $15 \%$ to the total upward flux (maximum at 14:30 with $4.4 \mathrm{nmol} \mathrm{m} \mathrm{m}^{-2} \mathrm{~s}^{-1}$ ). Methanol is mostly emitted by plants, e.g., by the plant growth metabolism (Wohlfahrt et al., 2015). From the wind rose in Fig. 7b it can be seen that the highest upward fluxes of methanol originated from the west.

The third-most emitted compound was acetone, which had a diurnal maximum upward flux at 11:30 with $1.0 \mathrm{nmol} \mathrm{m}^{-2} \mathrm{~s}^{-1}$. Its daily average contributed over $3 \%$ to the total upward flux (daily average). It has the same elemental composition as propanal. However, the contribution of propanal to the signal is normally less than $10 \%$ (de Gouw and Warneke, 2006). Acetone sources are ubiquitous: it can be emitted from several plants and trees (Geron et al., 2002; Fall, 1999), as well as from anthropogenic processes (Singh et al., 1994), or produced through secondary photochemical production (Goldstein and Schade, 2000).

The upward flux of acetaldehyde peaked around 11:30 at $0.7 \mathrm{nmol} \mathrm{m}^{-2} \mathrm{~s}^{-1}$. It is a hazardous air pollutant (EPA, 1994), and plays an important role in the formation of ozone, $\mathrm{HO}_{x}$ radicals (Singh et al., 1995) and PAN (Roberts, 1990).

The maximum upward flux of acetic acid was at 11:30 at $1.0 \mathrm{nmol} \mathrm{m} \mathrm{m}^{-2} \mathrm{~s}^{-1}$. Its sources are manifold: it is emitted by soil, vegetation and livestock; it can be produced photochemically; and it is also a combustion marker for biomass and fossil fuels (Chebbi and Carlier, 1996).

The $\mathrm{C}_{6}$ green leaf volatiles (GLVs; $\mathrm{C}_{6} \mathrm{H}_{13} \mathrm{O}^{+}$) are emitted by damaged plants seconds after the damage occurred (Holopainen, 2004). They are found to be important in "plant communication" and are used as "plant indirect defenses" (Scala et al., 2013, and references therein). The emission of GLVs accounted $1.2 \%$ of the total emission. Similar to the monoterpenes, a fragment of GLV $\left(\mathrm{C}_{6} \mathrm{H}_{11}^{+}\right.$; Table 2$)$ was also measured. But, unlike monoterpenes, the behavior of the parental ion and fragment is very different. While $\mathrm{C}_{6} \mathrm{H}_{13} \mathrm{O}^{+}$ has a downward flux / upward flux ratio of 0.3 (Sect. 3.6), the

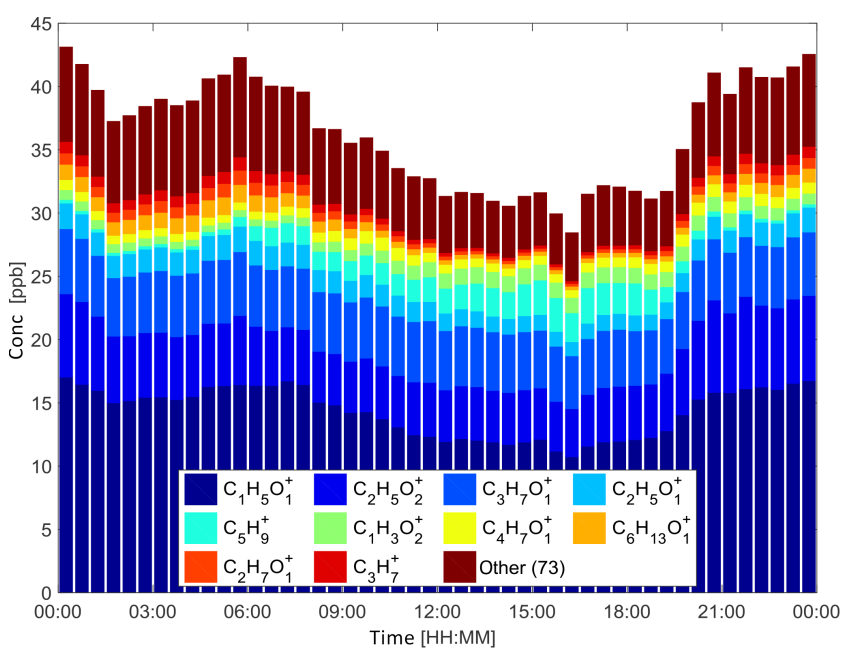

Figure 9. Diurnal average of the total VOC concentration resolved with the PTR-ToF (filtered for fragments). The 10 most abundant flux compounds are shown, the remaining compounds are summed up and plotted as "other". The time is in CET wintertime.

fragment's downward flux / upward flux ratio is $<1 \%$. This leads to the assumption that the fragmentation pattern for the main GLVs measured in Bosco Fontana is different.

Ethanol contributed $1.2 \%$ to the total upward flux. Ethanol is known to be emitted from different ecosystems, as shown in Park et al. (2013) and Kaser et al. (2013).

Other reported sources of carbonyls include conifers (e.g., Janson et al., 1999; Rinne et al., 2007) and decaying vegetation (e.g., de Gouw et al., 2000; Karl et al., 2001; Warneke et al., 2002). The remaining compounds each contributed less than $1 \%$ to the total upward flux.

\subsection{VOC deposition}

In the case of wet or dry deposition, the ambient concentration of the deposited compound plays an important role. Figure 9 shows the total VOC concentration detected by the PTR-ToF and its diurnal behavior. The highest total VOC concentrations occur during the night, when the planetary boundary layer is shallower and the volume, into which the VOCs are emitted, is smaller. However, concentrations of biogenic VOCs (e.g., isoprene, monoterpenes) were much smaller during the night, reflecting a combination of smaller emissions and influences from air from outside the forest (the footprint for concentration measurements is much larger than the Bosco Fontana forest). By contrast, long-lived compounds, which can also be of anthropogenic origin, increase in concentration at night. One of them, methanol, showed the largest concentration and biggest downward flux (Table 3). The wind rose for the methanol concentration is shown in Fig. 7b. The largest concentrations were measured when the wind direction was northeast and southwest. The downward flux of methanol generally lasted from 01:00 to 08:00. The 
Table 3. Compounds with downward flux, their daily averaged concentration, daily averaged downward flux, deposition velocity and respective lifetimes.

\begin{tabular}{lrrrr}
\hline Compound & $\begin{array}{r}\text { Concentration } \\
{[\mathrm{ppb}]}\end{array}$ & $\begin{array}{r}\text { Downward flux } \\
{\left[\mathrm{nmol} \mathrm{m}^{-2} \mathrm{~s}^{-1}\right]}\end{array}$ & $\begin{array}{r}\text { Lifetime } \\
{[\text { days }]}\end{array}$ & $\begin{array}{r}\text { Deposition velocity } \\
{\left[\mathrm{mm} \mathrm{s}^{-1}\right]}\end{array}$ \\
\hline methanol & 14.3 & 0.36 & $9^{\mathrm{a}}$ & 0.56 \\
acetic acid & 4.9 & 0.10 & $1.7^{\mathrm{b}}$ & 0.50 \\
$\mathrm{C}_{6} \mathrm{GLV}\left(\mathrm{C}_{6} \mathrm{H}_{13} \mathrm{O}_{1}^{+}\right)$ & 0.8 & 0.04 & - & 0.15 \\
ethanol & 0.6 & 0.02 & $2.8^{\mathrm{c}}$ & 0.55 \\
acetone & 4.7 & 0.01 & $15^{\mathrm{d}}$ & 0.05 \\
73.0255 & 0.2 & 0.01 & - & 1.4 \\
\hline
\end{tabular}

a Atmospheric lifetime according to Heikes et al. (2002). ${ }^{\text {b }}$ Lifetime in the boundary layer according to Paulot et al. (2011).

${ }^{c}$ Atmospheric lifetime according to Naik et al. (2010). ${ }^{d}$ Tropospheric lifetime according to Jacob et al. (2002).

methanol concentration also peaked during this period, indicating that the concentrations were considerably affected by horizontal transport or secondary production. Since the largest concentrations were measured at the same time when downward fluxes were observed, the source must have been located outside of the flux footprint. However, as the wind speed was below $2 \mathrm{~m} \mathrm{~s}^{-1}$, a major source is probably close to the measurement site. Overall methanol accounted for $63 \%$ to the total downward flux. The main sinks of methanol are reactions with $\mathrm{OH}$ and dry and wet deposition, which restrict the atmospheric lifetime of methanol to nine days (Heikes et al., 2002). Heikes et al. (2002) determined the average lifetime due to the gas reactions with $\mathrm{OH}$ to 18 days, while the lifetime with respect to deposition was calculated to be 24 days. Applying the same procedure for Bosco Fontana results in a deposition lifetime of 280 days, which reflects the different deposition velocities $\left(V_{\mathrm{d}}\right)$ used. For their estimate Heikes et al. (2002) used $V_{\mathrm{d}}=4 \mathrm{~mm} \mathrm{~s}^{-1}$, while in Bosco Fontana, the average deposition velocity was an order of magnitude lower, $0.55 \mathrm{~mm} \mathrm{~s}^{-1}$. As the measured downward flux is the sum of deposition and emission, just an upper limit of the deposition lifetime can be given. Additionally, the ambient humidity during the campaign was on average $55 \%$, which limits wet surfaces and thereby dry deposition. The global average also includes deposition over oceans, which is twice as fast as over land (Heikes et al., 2002).

The deposition of methanol has been observed in other studies (e.g., Holzinger et al., 2001; Goldan et al., 1995, Riemer et al., 1998; Rantala et al., 2015; Wohlfahrt et al., 2015). Laffineur et al. (2012) observed considerable methanol uptake, which they suggest to be caused by adsorption/desorption to water films. In the bottom panel of Fig. 10, the ambient, aerodynamic and dew point temperature are shown. The colored areas in the figure mark the standard deviation of the calculated temperatures. On the onset of methanol downward flux periods (Fig. 10 upper panel), the dew temperature and aerodynamic temperature are closest to each other and the relative humidity is around $65 \%$. The formation of dew is expected to happen during this time (01:00 to $06: 00)$. Interestingly, the downward flux increases during
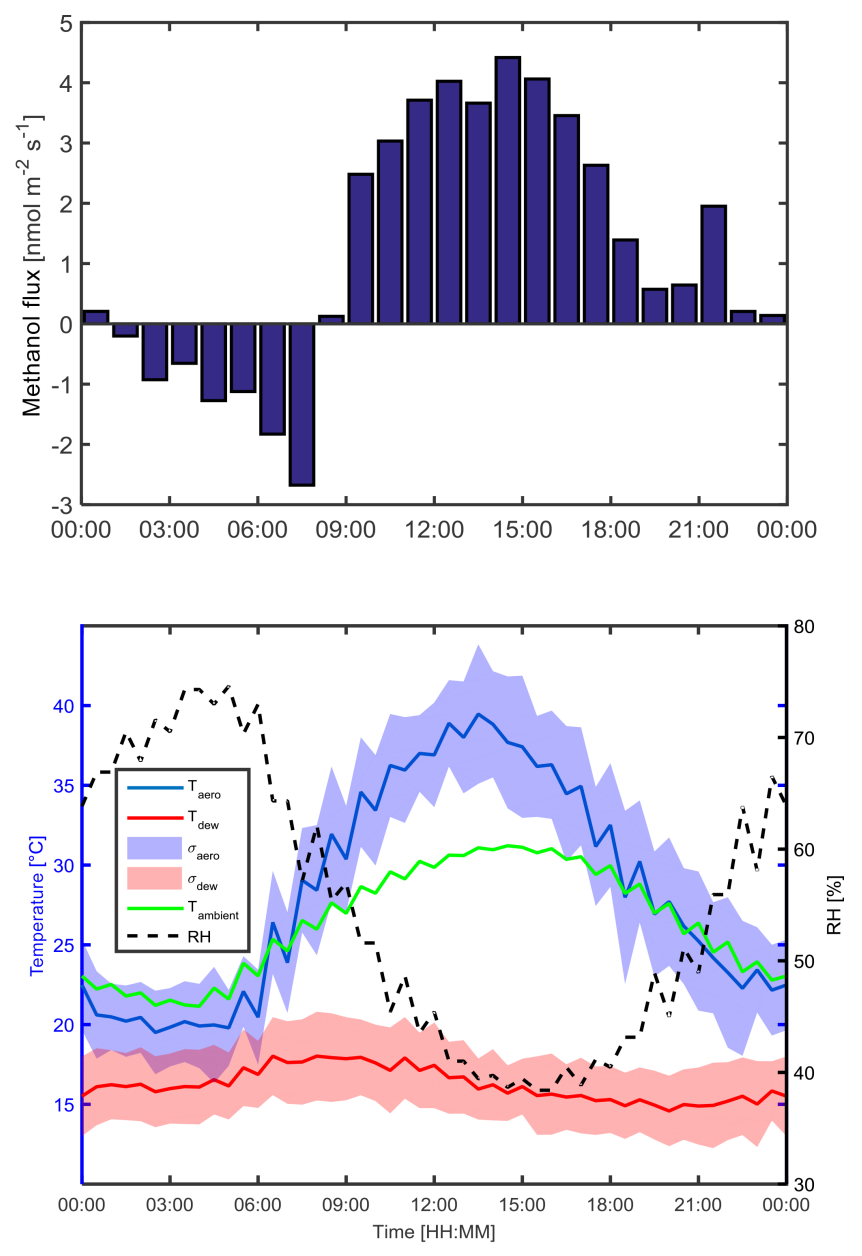

Figure 10. Diurnal exchange of the methanol (top panel) and the calculated aerodynamical $\left(T_{\text {aero }}\right)$, dew point $\left(T_{\text {dew }}\right)$ and ambient temperature $\left(T_{\mathrm{ambient}}\right.$; bottom panel). The blue and red shaded areas indicate the standard deviation of the calculated temperatures and the dashed line is the relative humidity. 
the night and reaches a maximum between 07:00 and 08:00, when the relative humidity has already decreased to $<60 \%$ and the difference between aerodynamic and dew point temperature is around $10^{\circ} \mathrm{C}$. After 08:00 the emissions dominate over the deposition, and for the rest of the day the methanol flux is positive.

Acetic acid showed the second highest downward flux, which contributed more than $16 \%$ to the total downward flux. It also had the second highest concentration (Table 3). Its lifetime is about 1.7 days in the boundary layer (Paulot et al., 2011).

With the elemental composition of $\mathrm{C}_{6} \mathrm{H}_{13} \mathrm{O}^{+}$(protonated) this $\mathrm{C}_{6} \mathrm{GLV}$ shows a higher downward flux (compare to its fragment $\mathrm{C}_{6} \mathrm{H}_{11}^{+}$), which explains $6 \%$ of the negative flux.

Ethanol had its maximum downward flux at 07:00 with $-0.11 \mathrm{nmol} \mathrm{m}^{-2} \mathrm{~s}^{-1}$, and it explains $3.5 \%$ of the total downward flux.

Next is acetone, which accounted for $1.7 \%$ to the total downward flux. It had the third highest concentration (Table 3 ) and the tropospheric lifetime is reported to be 15 days (Jacob et al., 2002).

An unidentified compound with the mass $73.0255 \mathrm{amu}$ caused $1.6 \%$ of the total downward flux, while the remaining compounds each contributed less than $1 \%$.

\section{Conclusions}

During the Bosco Fontana campaign, up to 29 (depending on method and sigma threshold) compounds were found to have a detectable flux. The VOC exchange was dominated by isoprene which comprised over $65 \%$ of the total net flux (on a molar basis). The high isoprene flux influenced the MVK/MACR flux via atmospheric oxidation. The calculated chemical production was able to explain up to $30 \%$ of the measured MVK/MACR flux. Thus, the major part of the MVK/MACR flux remained unaccounted and further research is needed to identify its sources.
Methanol caused over $60 \%$ of the total downward flux, which happened during the early morning. The removal was assumed to be dry deposition to water films on surfaces (including dew) as the downward fluxes coincided with the calculated ratios of dew point to aerodynamic temperature approaching unity. The deposition lifetime of methanol was estimated to be long compared to the global mean, which might be explained by the dry conditions at Bosco Fontana during the measurement period.

Overall, five compounds caused over $90 \%$ of the total downward flux $\left(-0.58 \mathrm{nmol} \mathrm{m}^{-2} \mathrm{~s}^{-1}\right)$, and seven compounds add up to over $90 \%$ of the total upward flux $\left(10.4 \mathrm{nmol} \mathrm{m}^{-2} \mathrm{~s}^{-1}\right)$. The measured VOCs contribute with less than $2 \%$ to the net exchange of carbon by $\mathrm{CO}_{2}$.

Comparing the results with the emissions from an orange grove (Park et al., 2013), our study found far fewer compounds that showed significant exchange. The sigma criteria (3-10) used for the compound with detectable flux classification had only a minor effect on total VOC upward and downward fluxes. The largest difference in the net VOC exchange between Bosco Fontana and the orange orchard was the dominance of isoprene upward flux at Bosco Fontana, while the fluxes of other major compounds were comparable between the two measurement sites.

The manual method, which searches for CCF maxima manually, detected over $80 \%$ of the upward flux, $49 \%$ of the downward flux and $84 \%$ of the net flux compared with the automated method, which uses a routine to find masses with flux. Thus, this study recommends the automated method, as the fast analysis, objective criteria and better flux detection are valuable assets for calculating and classifying fluxes of several hundred different ion peaks. 


\section{Appendix A}

Table A1. Information about all 164 measured mass peaks in Bosco Fontana. The limit of detection is given for the calibrated masses. Masses with an F in the last column are filtered out as they were identified as fragments or clusters.

\begin{tabular}{|c|c|c|c|c|}
\hline $\begin{array}{l}\text { Mass } \\
\text { [amu] }\end{array}$ & $\begin{array}{l}\text { Elem. } \\
\text { comp. }\end{array}$ & Background & $\begin{array}{r}\text { Sigma } \\
\text { threshold }\end{array}$ & $\begin{array}{r}\text { LOD (30 min); } \\
\text { frag. }\end{array}$ \\
\hline 21.0221 & $\left.\mathrm{H}_{3}{ }^{18} \mathrm{O}_{1}^{+}\right]$ & 1 & 8.29 & \\
\hline 27.0229 & $\mathrm{C}_{2} \mathrm{H}_{3}^{+}$ & 1 & -0.09 & \\
\hline 28.0056 & $\mathrm{~N}_{2}^{+}$ & 1 & 1.94 & \\
\hline 29.0134 & $\mathrm{H}_{1} \mathrm{~N}_{2}^{+}$ & 1 & 35.03 & \\
\hline 29.9974 & $\mathrm{O}_{1} \mathrm{~N}_{1}^{7}$ & 1 & 3.04 & \\
\hline 31.0178 & $\mathrm{C}_{1} \mathrm{H}_{3} \mathrm{O}_{1}^{+}$ & 1 & 6.12 & \\
\hline 31.9893 & $\mathrm{O}_{2}^{+}$ & 1 & 162.67 & \\
\hline 32.9971 & $\mathrm{H}_{1}^{2} \mathrm{O}_{2}^{+}$ & 1 & 3.42 & \\
\hline 33.0335 & $\mathrm{C}_{1} \mathrm{H}_{5} \mathrm{O}_{1}^{+}$ & 0 & 45.69 & 38.5 \\
\hline 35.0366 & $\mathrm{H}_{5} \mathrm{O}_{1} \mathrm{~N}_{1}^{+}$ & 0 & 8.77 & \\
\hline 36.0206 & $\mathrm{H}_{4} \mathrm{O}_{2}^{+}$ & 1 & 1.98 & \\
\hline 36.0444 & $\mathrm{H}_{6} \mathrm{O}_{1} \mathrm{~N}_{1}^{+}$ & 1 & 19.26 & \\
\hline 37.0284 & $\mathrm{H}_{5} \mathrm{O}_{2}^{+}$ & 1 & 36.46 & \\
\hline 38.0362 & $\mathrm{H}_{6} \mathrm{O}_{2}^{+}$ & 1 & 159.67 & \\
\hline 39.9629 & & 1 & 1.42 & \\
\hline 40.9710 & & 1 & 1.74 & \\
\hline 41.0386 & $\mathrm{C}_{3} \mathrm{H}_{5}^{+}$ & 0 & 156.77 & $\mathrm{~F}$ \\
\hline 42.0100 & $\mathrm{C}_{2} \mathrm{H}_{2} \mathrm{O}_{1}^{+}$ & 0 & -1.53 & \\
\hline 42.0338 & $\mathrm{C}_{2} \mathrm{H}_{4} \mathrm{~N}_{1}^{+}$ & 0 & 6.26 & 5.1 \\
\hline 43.0178 & $\mathrm{C}_{2} \mathrm{H}_{3} \mathrm{O}_{1}^{+}$ & 0 & 10.57 & $\mathrm{~F}$ \\
\hline 43.0542 & $\mathrm{C}_{3} \mathrm{H}_{7}^{+}$ & 0 & 5.13 & \\
\hline 44.0138 & & 0 & 1.74 & \\
\hline 44.9971 & $\mathrm{C}_{1} \mathrm{H}_{1} \mathrm{O}_{2}^{+}$ & 1 & 2.63 & \\
\hline 45.0335 & $\mathrm{C}_{2} \mathrm{H}_{5} \mathrm{O}_{1}^{+}$ & 0 & 15.53 & 13.2 \\
\hline 45.9924 & $\mathrm{O}_{2} \mathrm{~N}_{1}^{+}$ & 1 & 3.27 & \\
\hline 46.0287 & $\mathrm{C}_{1} \mathrm{H}_{4} \mathrm{O}_{1} \mathrm{~N}_{1}^{+}$ & 0 & 2.46 & \\
\hline 47.0128 & $\mathrm{C}_{1} \mathrm{H}_{3} \mathrm{O}_{2}^{+}$ & 0 & 2.92 & \\
\hline 47.0240 & $\mathrm{H}_{3} \mathrm{O}_{1} \mathrm{~N}_{2}^{+}$ & 1 & 59.34 & \\
\hline 47.0491 & $\mathrm{C}_{2} \mathrm{H}_{7} \mathrm{O}_{1}^{+}$ & 0 & 8.74 & \\
\hline 48.0080 & $\mathrm{H}_{2} \mathrm{O}_{2} \mathrm{~N}_{1}^{+}$ & 1 & 4.87 & \\
\hline 49.0284 & $\mathrm{C}_{1} \mathrm{H}_{5} \mathrm{O}_{2}^{+}$ & 0 & 1.31 & \\
\hline 49.9998 & $\mathrm{H}_{2} \mathrm{O}_{3}^{+}$ & 1 & -0.34 & \\
\hline 51.0077 & $\mathrm{H}_{3} \mathrm{O}_{3}^{+}$ & 1 & 5.73 & \\
\hline 51.0441 & $\mathrm{C}_{1} \mathrm{H}_{7} \mathrm{O}_{2}^{+}$ & 0 & 26.53 & $\mathrm{~F}$ \\
\hline 51.9382 & & 1 & -1.63 & \\
\hline 51.9944 & $\mathrm{C}_{3} \mathrm{O}_{1}^{+}$ & 1 & -0.68 & \\
\hline 53.0022 & $\mathrm{C}_{3} \mathrm{H}_{1} \mathrm{O}_{1}^{+}$ & 1 & -0.30 & \\
\hline 53.0386 & $\mathrm{C}_{4} \mathrm{H}_{5}^{+}$ & 0 & 3.59 & \\
\hline 53.9394 & & 1 & -0.14 & \\
\hline 55.0390 & $\mathrm{H}_{7} \mathrm{O}_{3}^{+}$ & 1 & 167.77 & \\
\hline 55.9377 & & 1 & 2.88 & \\
\hline 56.0468 & $\mathrm{H}_{8} \mathrm{O}_{3}^{+}$ & 1 & 7.35 & \\
\hline 57.0335 & $\mathrm{C}_{3} \mathrm{H}_{5} \mathrm{O}_{1}^{+}$ & 0 & 19.26 & 6.9 \\
\hline 57.0699 & $\mathrm{C}_{4} \mathrm{H}_{9}^{+}$ & 1 & 12.76 & \\
\hline 57.9352 & & 1 & -0.86 & \\
\hline 59.0491 & $\mathrm{C}_{3} \mathrm{H}_{7} \mathrm{O}_{1}^{+}$ & 0 & 15.82 & 6.1 \\
\hline 60.0481 & & 0 & 1.42 & \\
\hline 61.0284 & $\mathrm{C}_{2} \mathrm{H}_{5} \mathrm{O}_{2}^{+}$ & 0 & 11.79 & \\
\hline 62.0237 & $\mathrm{C}_{1} \mathrm{H}_{4} \mathrm{O}_{2} \mathrm{~N}_{1}^{+}$ & 0 & 0.84 & \\
\hline 63.0263 & $\mathrm{C}_{2} \mathrm{H}_{7} \mathrm{~S}_{1}^{+}$ & 0 & 1.60 & \\
\hline 63.9852 & $\mathrm{H}_{2} \mathrm{O}_{1} \mathrm{~N}_{1} \mathrm{~S}_{1}^{+}$ & 0 & -1.30 & \\
\hline 65.0233 & $\mathrm{C}_{1} \mathrm{H}_{5} \mathrm{O}_{3}^{+}$ & 0 & 5.84 & \\
\hline
\end{tabular}

Table A1. Continued.

\begin{tabular}{|c|c|c|c|c|}
\hline 65.0584 & $\mathrm{H}_{7} \mathrm{O}_{1} \mathrm{~N}_{3}^{+}$ & 0 & 1.59 & \\
\hline 67.0542 & $\mathrm{C}_{5} \mathrm{H}_{7}^{+}$ & 0 & 64.76 & $\mathrm{~F}$ \\
\hline 68.0621 & $\mathrm{C}_{5} \mathrm{H}_{8}^{+}$ & 0 & 96.03 & $\mathrm{~F}$ \\
\hline 69.0699 & $\mathrm{C}_{5} \mathrm{H}_{9}^{+}$ & 0 & 241.62 & 2.8 \\
\hline 71.0491 & $\mathrm{C}_{4} \mathrm{H}_{7} \mathrm{O}_{1}^{+}$ & 0 & 39.95 & 4.7 \\
\hline 71.0851 & $\mathrm{C}_{5} \mathrm{H}_{11}^{+}$ & 0 & 7.47 & \\
\hline 72.0875 & & 0 & 6.68 & \\
\hline 73.0255 & & 0 & 3.63 & \\
\hline 73.0473 & & 0 & 0.73 & \\
\hline 73.0648 & $\mathrm{C}_{4} \mathrm{H}_{9} \mathrm{O}_{1}^{+}$ & 0 & 9.64 & 2.1 \\
\hline 74.0227 & & 0 & 0.75 & \\
\hline 75.0441 & $\mathrm{C}_{3} \mathrm{H}_{7} \mathrm{O}_{2}^{+}$ & 0 & 11.07 & \\
\hline 75.9436 & $\mathrm{C}_{1} \mathrm{~S}_{2}^{+}$ & 1 & 0.51 & \\
\hline 77.9424 & & 1 & -0.60 & \\
\hline 79.0542 & $\mathrm{C}_{6} \mathrm{H}_{7}^{+}$ & 0 & 3.44 & 2.5 \\
\hline 80.9971 & $\mathrm{C}_{4} \mathrm{H}_{1} \mathrm{O}_{2}^{+}$ & 0 & -0.80 & \\
\hline 81.0335 & $\mathrm{C}_{5} \mathrm{H}_{5} \mathrm{O}_{1}^{7}$ & 1 & 10.76 & \\
\hline 81.0699 & $\mathrm{C}_{6} \mathrm{H}_{9}^{+}$ & 0 & 106.38 & $\mathrm{~F}$ \\
\hline 83.0523 & & 0 & 1.47 & \\
\hline 83.0855 & $\mathrm{C}_{6} \mathrm{H}_{11}^{+}$ & 0 & 15.80 & \\
\hline 85.0284 & $\mathrm{C}_{4} \mathrm{H}_{5} \mathrm{O}_{2}^{+}$ & 0 & 1.50 & \\
\hline 85.0648 & $\mathrm{C}_{5} \mathrm{H}_{9} \mathrm{O}_{1}^{+}$ & 0 & 12.14 & \\
\hline 85.1012 & $\mathrm{C}_{6} \mathrm{H}_{13}^{+}$ & 0 & 1.30 & \\
\hline 85.9471 & & 1 & 1.27 & \\
\hline 87.0441 & $\mathrm{C}_{4} \mathrm{H}_{7} \mathrm{O}_{2}^{+}$ & 0 & 1.58 & \\
\hline 87.0804 & $\mathrm{C}_{5} \mathrm{H}_{11} \mathrm{O}_{1}^{+}$ & 0 & 1.61 & \\
\hline 88.0763 & & 0 & 1.14 & \\
\hline 88.9555 & $\mathrm{H}_{3} \mathrm{O}_{1} \mathrm{Cl}_{2}^{+}$ & 1 & 0.42 & \\
\hline 89.0233 & $\mathrm{C}_{3} \mathrm{H}_{5} \mathrm{O}_{3}^{+}$ & 0 & 3.58 & \\
\hline 89.0597 & $\mathrm{C}_{4} \mathrm{H}_{9} \mathrm{O}_{2}^{+}$ & 0 & 0.99 & \\
\hline 90.9487 & & 1 & 7.58 & \\
\hline 91.0567 & & 0 & 1.16 & \\
\hline 91.9457 & & 1 & 1.79 & \\
\hline 92.9480 & & 1 & 2.59 & \\
\hline 93.0369 & $\mathrm{C}_{3} \mathrm{H}_{9} \mathrm{O}_{1} \mathrm{~S}_{1}^{+}$ & 1 & 6.19 & \\
\hline 93.0699 & $\mathrm{C}_{7} \mathrm{H}_{9}^{+}$ & 0 & 1.79 & 0.7 \\
\hline 93.9542 & $\mathrm{C}_{1} \mathrm{H}_{2} \mathrm{O}_{1} \mathrm{~S}_{2}^{+}$ & 1 & -2.91 & \\
\hline 95.0161 & $\mathrm{C}_{2} \mathrm{H}_{7} \mathrm{O}_{2} \mathrm{~S}_{1}^{7}$ & 0 & -0.06 & \\
\hline 95.0478 & $\mathrm{C}_{4} \mathrm{H}_{5} \mathrm{~N}_{3}^{+}$ & 0 & 1.20 & \\
\hline 95.0855 & $\mathrm{C}_{7} \mathrm{H}_{11}^{+}$ & 0 & 8.87 & $\mathrm{~F}$ \\
\hline 95.9512 & $\mathrm{O}_{4} \mathrm{~S}_{1}^{\neq^{+}}$ & 1 & 1.38 & \\
\hline 96.9961 & & 0 & 1.10 & \\
\hline 97.0284 & $\mathrm{C}_{5} \mathrm{H}_{5} \mathrm{O}_{2}^{+}$ & 0 & 3.04 & \\
\hline 97.0634 & $\mathrm{C}_{4} \mathrm{H}_{7} \mathrm{~N}_{3}^{7}$ & 0 & 2.96 & \\
\hline 97.1012 & $\mathrm{C}_{7} \mathrm{H}_{13}^{+}$ & 0 & 1.00 & \\
\hline 98.0237 & $\mathrm{C}_{4} \mathrm{H}_{4} \mathrm{O}_{2} \mathrm{~N}_{1}^{+}$ & 1 & -1.51 & \\
\hline 98.0600 & $\mathrm{C}_{5} \mathrm{H}_{8} \mathrm{O}_{1} \mathrm{~N}_{1}^{+}$ & 0 & 1.43 & \\
\hline 99.0077 & $\mathrm{C}_{4} \mathrm{H}_{3} \mathrm{O}_{3}^{+}$ & 0 & 0.34 & \\
\hline 99.0441 & $\mathrm{C}_{5} \mathrm{H}_{7} \mathrm{O}_{2}^{+}$ & 0 & 6.23 & \\
\hline 99.0804 & $\mathrm{C}_{6} \mathrm{H}_{11} \mathrm{O}_{1}^{+}$ & 0 & 6.69 & \\
\hline 100.0393 & $\mathrm{C}_{4} \mathrm{H}_{6} \mathrm{O}_{2} \mathrm{~N}_{1}^{+}$ & 1 & 0.08 & \\
\hline 100.0757 & $\mathrm{C}_{5} \mathrm{H}_{10} \mathrm{O}_{1} \mathrm{~N}_{1}^{+}$ & 1 & -0.90 & \\
\hline 101.0233 & $\mathrm{C}_{4} \mathrm{H}_{5} \mathrm{O}_{3}^{+}$ & 0 & -1.69 & \\
\hline 101.0597 & $\mathrm{C}_{5} \mathrm{H}_{9} \mathrm{O}_{2}^{+}$ & 0 & 5.07 & \\
\hline 101.0961 & $\mathrm{C}_{6} \mathrm{H}_{13} \mathrm{O}_{1}^{+}$ & 0 & 3.11 & 18.7 \\
\hline 101.9428 & & 0 & 0.35 & \\
\hline 102.0913 & $\mathrm{C}_{5} \mathrm{H}_{12} \mathrm{O}_{1} \mathrm{~N}_{1}^{+}$ & 0 & 0.57 & \\
\hline 102.9468 & & 0 & -0.23 & \\
\hline 103.0390 & $\mathrm{C}_{4} \mathrm{H}_{7} \mathrm{O}_{3}^{+}$ & 0 & 1.35 & \\
\hline
\end{tabular}


Table A1. Continued.

\begin{tabular}{|c|c|c|c|c|}
\hline 103.0754 & $\mathrm{C}_{5} \mathrm{H}_{11} \mathrm{O}_{2}^{+}$ & 0 & 2.90 & \\
\hline 103.9516 & $\mathrm{H}_{5} \mathrm{~S}_{2} \mathrm{Cl}_{1}^{+}$ & 1 & 0.17 & \\
\hline 105.9359 & & 1 & 1.19 & \\
\hline 106.9418 & & 1 & 0.07 & \\
\hline 106.9617 & & 0 & 0.61 & \\
\hline 107.0491 & $\mathrm{C}_{7} \mathrm{H}_{7} \mathrm{O}_{1}^{+}$ & 0 & 1.47 & \\
\hline 107.0855 & $\mathrm{C}_{8} \mathrm{H}_{11}^{+}$ & 0 & 0.58 & 0.4 \\
\hline 107.9512 & $\mathrm{C}_{1} \mathrm{O}_{4} \mathrm{~S}_{1}^{+}$ & 1 & 2.75 & \\
\hline 108.9590 & $\mathrm{C}_{1} \mathrm{H}_{1} \mathrm{O}_{4} \mathrm{~S}_{1}^{+}$ & 1 & 2.88 & \\
\hline 108.9920 & $\mathrm{C}_{5} \mathrm{H}_{1} \mathrm{O}_{3}^{+}$ & 1 & -0.03 & \\
\hline 109.0284 & $\mathrm{C}_{6} \mathrm{H}_{5} \mathrm{O}_{2}^{+}$ & 0 & -3.77 & \\
\hline 109.0648 & $\mathrm{C}_{7} \mathrm{H}_{9} \mathrm{O}_{1}^{+}$ & 0 & 2.71 & \\
\hline 109.1012 & $\mathrm{C}_{8} \mathrm{H}_{13}^{+}$ & 0 & 1.06 & \\
\hline 111.0441 & $\mathrm{C}_{6} \mathrm{H}_{7} \mathrm{O}_{2}^{+}$ & 1 & 1.08 & \\
\hline 111.0804 & $\mathrm{C}_{7} \mathrm{H}_{11} \mathrm{O}_{1}^{+}$ & 1 & 1.28 & \\
\hline 111.1168 & $\mathrm{C}_{8} \mathrm{H}_{15}^{+}$ & 0 & -0.31 & \\
\hline 111.9461 & $\mathrm{O}_{5} \mathrm{~S}_{1}^{+}$ & 1 & -0.89 & \\
\hline 113.0597 & $\mathrm{C}_{6} \mathrm{H}_{9} \mathrm{O}_{2}^{+}$ & 0 & -0.83 & \\
\hline 113.0947 & $\mathrm{C}_{5} \mathrm{H}_{11} \mathrm{~N}_{3}^{+}$ & 0 & 2.37 & \\
\hline 115.0096 & & 1 & 1.31 & \\
\hline 115.0363 & $\mathrm{C}_{1} \mathrm{H}_{3} \mathrm{O}_{1} \mathrm{~N}_{6}^{+}$ & 0 & -1.02 & \\
\hline 115.0754 & $\mathrm{C}_{6} \mathrm{H}_{11} \mathrm{O}_{2}^{+}$ & 0 & 2.18 & \\
\hline 115.1117 & $\mathrm{C}_{7} \mathrm{H}_{15} \mathrm{O}_{1}^{7}$ & 0 & -0.24 & \\
\hline 116.9060 & $\mathrm{C}_{1} \mathrm{Cl}_{3}^{+}$ & 0 & -0.28 & \\
\hline 117.9542 & $\mathrm{C}_{3} \mathrm{H}_{2} \mathrm{O}_{1} \mathrm{~S}_{2}^{+}$ & 1 & -2.30 & \\
\hline 118.9451 & & 0 & -3.19 & \\
\hline 119.9512 & $\mathrm{C}_{2} \mathrm{O}_{4} \mathrm{~S}_{1}^{+}$ & 1 & -0.03 & \\
\hline 120.9534 & & 0 & -1.06 & \\
\hline 121.0648 & $\mathrm{C}_{8} \mathrm{H}_{9} \mathrm{O}_{1}^{+}$ & 0 & 0.10 & \\
\hline 121.1012 & $\mathrm{C}_{9} \mathrm{H}_{13}^{+}$ & 0 & 0.78 & 0.4 \\
\hline 123.0441 & $\mathrm{C}_{7} \mathrm{H}_{7} \mathrm{O}_{2}^{+}$ & 1 & 0.20 & \\
\hline 123.1168 & $\mathrm{C}_{9} \mathrm{H}_{15}^{+}$ & 0 & 1.78 & \\
\hline 123.9440 & & 1 & 10.14 & \\
\hline 124.9510 & $\mathrm{C}_{1} \mathrm{O}_{4} \mathrm{~N}_{1} \mathrm{Cl}_{1}^{+}$ & 1 & -1.66 & \\
\hline 125.9572 & & 1 & -0.85 & \\
\hline 126.0159 & $\mathrm{C}_{2} \mathrm{H}_{6} \mathrm{O}_{6}^{+}$ & 1 & 1.45 & \\
\hline 126.0557 & & 1 & 1.71 & \\
\hline 126.0957 & & 1 & 0.30 & \\
\hline 127.0390 & $\mathrm{C}_{6} \mathrm{H}_{7} \mathrm{O}_{3}^{+}$ & 0 & 1.84 & \\
\hline 127.0754 & $\mathrm{C}_{7} \mathrm{H}_{11} \mathrm{O}_{2}^{+}$ & 1 & -1.93 & \\
\hline 127.1117 & $\mathrm{C}_{8} \mathrm{H}_{15} \mathrm{O}_{1}^{7}$ & 0 & -0.12 & \\
\hline 128.1107 & & 1 & -0.39 & \\
\hline 130.9920 & & 1 & 1.39 & \\
\hline 135.0406 & & 0 & 4.35 & \\
\hline 137.0557 & & 0 & 2.16 & \\
\hline 137.1325 & $\mathrm{C}_{10} \mathrm{H}_{17}^{+}$ & 0 & 115.45 & 0.5 \\
\hline 138.0590 & & 1 & 30.15 & \\
\hline 140.0304 & & 1 & 1.14 & \\
\hline 140.0751 & & 1 & -1.76 & \\
\hline 144.9606 & $\mathrm{C}_{6} \mathrm{H}_{3} \mathrm{Cl}_{2}^{+}$ & 1 & 0.69 & \\
\hline 145.9685 & $\mathrm{C}_{6} \mathrm{H}_{4} \mathrm{Cl}_{2}^{7}$ & 1 & -0.02 & \\
\hline 180.9373 & $\mathrm{Cl}_{3} \mathrm{C}_{6} \mathrm{H}_{4}^{7}$ & 1 & 2.40 & \\
\hline
\end{tabular}

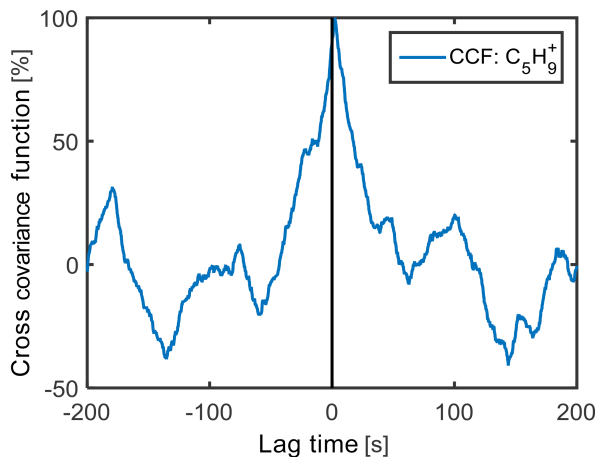

Figure A1. Thirty-minute cross covariance function of $\mathrm{C}_{5} \mathrm{H}_{9}^{+}$from 15 June 2012, 14:15. The function was normalized to the maximum. A clear maximum can be seen, slightly shifted to the right by the lag time.

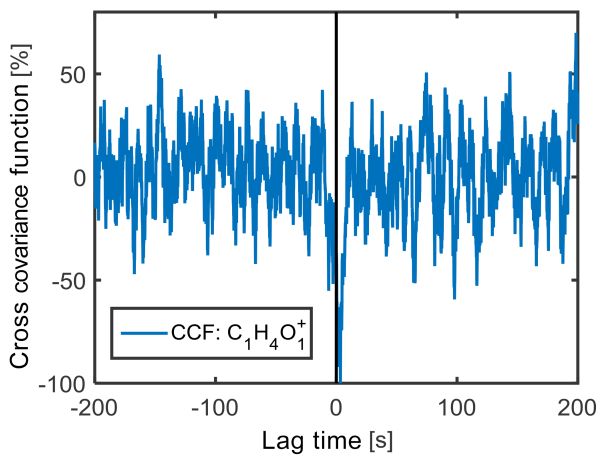

Figure A2. Thirty-minute normalized cross covariance function of $\mathrm{C}_{1} \mathrm{H}_{4} \mathrm{O}_{1}^{+}$from 22 June 2012, 04:45. A clear minima can be seen, which defines downward fluxes.

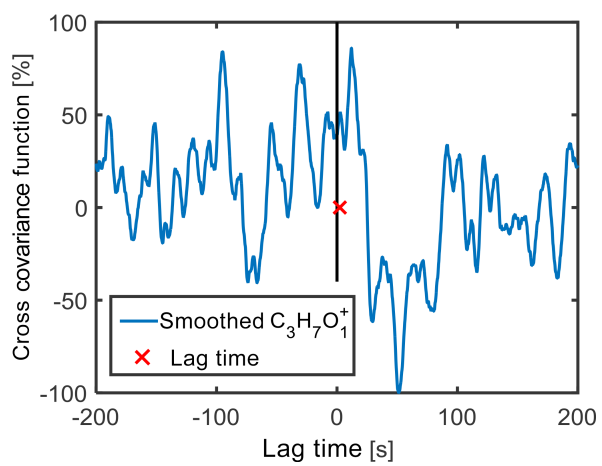

Figure A3. Smoothed normalized $\mathrm{CCF}$ of $\mathrm{C}_{3} \mathrm{H}_{7} \mathrm{O}_{1}^{+}$. The red cross marks the lag time used in the original CCF (Fig. A4) to find the flux value; the allowed lag time window is from 0 to $5 \mathrm{~s}$. In this specific CCF only a local maximum was found, as there is no clear maximum 
Table A2. Comparison of the detected compounds with flux in Bosco Fontana and their values at the orange grove (Park et al., 2013).

\begin{tabular}{|c|c|c|c|}
\hline \multirow[t]{2}{*}{$\begin{array}{l}\text { Elemental } \\
\text { composition }\end{array}$} & Mass & \multicolumn{2}{|c|}{$\begin{array}{l}\text { Net (downward/upward) flux } \\
\text { (24h average) }\left[\mathrm{nmol} \mathrm{m}{ }^{-2} \mathrm{~s}^{-1}\right]\end{array}$} \\
\hline & [amu] & this study & Park et al. (2013) ${ }^{1}$ \\
\hline $\mathrm{C}_{1} \mathrm{H}_{5} \mathrm{O}_{1}^{+}$ & 33.0335 & $1.168(-0.365 / 1.533)$ & $1.655(-0.102 / 1.757)$ \\
\hline $\mathrm{H}_{5} \mathrm{O}_{1} \mathrm{~N}_{1}^{+}$ & 35.0366 & $0.061(-0.002 / 0.064)$ & \\
\hline $\mathrm{C}_{2} \mathrm{H}_{4} \mathrm{~N}_{1}^{+}$ & 42.0338 & $0.046(-0.005 / 0.051)$ & \\
\hline $\mathrm{C}_{3} \mathrm{H}_{7}^{+}$ & 43.0542 & $0.079(-0.005 / 0.084)$ & $0.075(-0.001 / 0.076)$ \\
\hline $\mathrm{C}_{2} \mathrm{H}_{5} \mathrm{O}_{1}^{+}$ & 45.0335 & $0.228(-0.001 / 0.229)$ & $0.133(-0.016 / 0.148)$ \\
\hline $\mathrm{C}_{2} \mathrm{H}_{7} \mathrm{O}_{1}^{+}$ & 47.0491 & $0.105(-0.02 / 0.125)$ & $-0.013(-0.017 / 0.004)$ \\
\hline $\mathrm{C}_{4} \mathrm{H}_{5}^{+}$ & 53.0386 & $0.008(-0.001 / 0.009)$ & $0.012(-0.009 / 0.021)$ \\
\hline $\mathrm{C}_{3} \mathrm{H}_{5} \mathrm{O}_{1}^{+}$ & 57.0335 & $0.085(-0.002 / 0.086)$ & $0.033(-0.016 / 0.049)$ \\
\hline $\mathrm{C}_{3} \mathrm{H}_{7} \mathrm{O}_{1}^{+}$ & 59.0491 & $0.335(-0.01 / 0.345)$ & $0.281(-0.004 / 0.286)$ \\
\hline $\mathrm{C}_{2} \mathrm{H}_{5} \mathrm{O}_{2}^{+}$ & 61.0284 & $0.214(-0.096 / 0.311)$ & $0.413(-0.005 / 0.418)$ \\
\hline $\mathrm{C}_{1} \mathrm{H}_{5} \mathrm{O}_{3}^{+}$ & 65.0233 & $0.03(-0.001 / 0.031)$ & \\
\hline $\mathrm{C}_{5} \mathrm{H}_{9}^{+}$ & 69.0699 & $6.466(0 / 6.466)$ & $0.025(-0.001 / 0.025)$ \\
\hline $\mathrm{C}_{4} \mathrm{H}_{7} \mathrm{O}_{1}^{+}$ & 71.0491 & $0.311(-0.004 / 0.315)$ & $0.041(-0.004 / 0.044)$ \\
\hline $\mathrm{C}_{5} \mathrm{H}_{11}+$ & 71.0851 & $0.02(-0.001 / 0.021)$ & $0.006(-0.005 / 0.011)$ \\
\hline unknown & 72.0875 & $0.015(-0.002 / 0.016)$ & \\
\hline unknown & 73.0255 & $0.026(-0.009 / 0.035)$ & \\
\hline $\mathrm{C}_{4} \mathrm{H}_{9} \mathrm{O}_{1}^{+}$ & 73.0648 & $0.075(-0.002 / 0.077)$ & $0.029(-0.007 / 0.036)$ \\
\hline $\mathrm{C}_{3} \mathrm{H}_{7} \mathrm{O}_{2}^{+}$ & 75.0441 & $0.068(-0.005 / 0.073)$ & \\
\hline $\mathrm{C}_{6} \mathrm{H}_{7}^{+}$ & 79.0542 & $0.021(-0.002 / 0.023)$ & $0.016(-0.002 / 0.018)$ \\
\hline $\mathrm{C}_{6} \mathrm{H}_{11}^{+}$ & 83.0855 & $0.034(0 / 0.035)$ & $0.007(-0.004 / 0.011)$ \\
\hline $\mathrm{C}_{5} \mathrm{H}_{9} \mathrm{O}_{1}^{+}$ & 85.0648 & $0.017(-0.001 / 0.018)$ & $0.008(-0.005 / 0.013)$ \\
\hline $\mathrm{C}_{3} \mathrm{H}_{5} \mathrm{O}_{3}^{+}$ & 89.0233 & $0.011(-0.001 / 0.012)$ & $0.007(-0.004 / 0.011)$ \\
\hline $\mathrm{C}_{5} \mathrm{H}_{5} \mathrm{O}_{2}^{+}$ & 97.0284 & $0(-0.002 / 0.002)$ & $0.007(-0.005 / 0.012)$ \\
\hline $\mathrm{C}_{4} \mathrm{H}_{7} \mathrm{~N}_{3}^{+}$ & 97.0634 & $0.003(-0.001 / 0.004)$ & $0.007(-0.007 / 0.015)$ \\
\hline $\mathrm{C}_{5} \mathrm{H}_{7} \mathrm{O}_{2}^{+}$ & 99.0441 & $0.017(-0.001 / 0.018)$ & $0.008(-0.004 / 0.012)$ \\
\hline $\mathrm{C}_{6} \mathrm{H}_{11} \mathrm{O}_{1}^{+}$ & 99.0804 & $0.014(-0.001 / 0.014)$ & \\
\hline $\mathrm{C}_{5} \mathrm{H}_{9} \mathrm{O}_{2}^{+}$ & 101.0597 & $0.014(-0.001 / 0.014)$ & $0.004(-0.003 / 0.008)$ \\
\hline $\mathrm{C}_{6} \mathrm{H}_{13} \mathrm{O}_{1}^{+}$ & 101.0961 & $0.091(-0.037 / 0.128)$ & \\
\hline $\mathrm{C}_{10} \mathrm{H}_{17}^{+}$ & 137.1325 & $0.219(-0.001 / 0.219)$ & $0.235(0 / 0.236)^{2}$ \\
\hline
\end{tabular}

${ }^{1}$ The presented data were calculated from Table S2 in the Supplement. ${ }^{2}$ The fragments of monoterpenes were summed up to be comparable with the upscaled monoterpene signal from Bosco Fontana. 


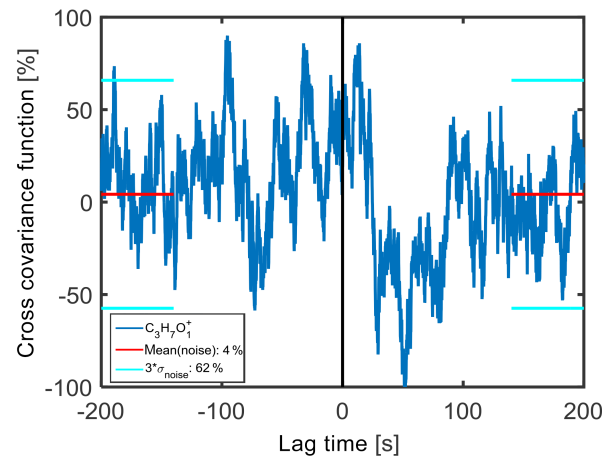

Figure A4. Thirty-minute normalized cross covariance function of $\mathrm{C}_{3} \mathrm{H}_{7} \mathrm{O}_{1}^{+}$from 15 June 2012, 14:15. No clear maximum or minimum can be seen around $0 \mathrm{~s}$ lag time. The red lines at the corners of the plot indicate the average noise, while the cyan lines are the $3 \sigma_{\text {noise }}$ threshold (in the legend the $62 \%$ represents just the $3 \sigma_{\text {noise }}$, while in the plot it is added to the mean noise).

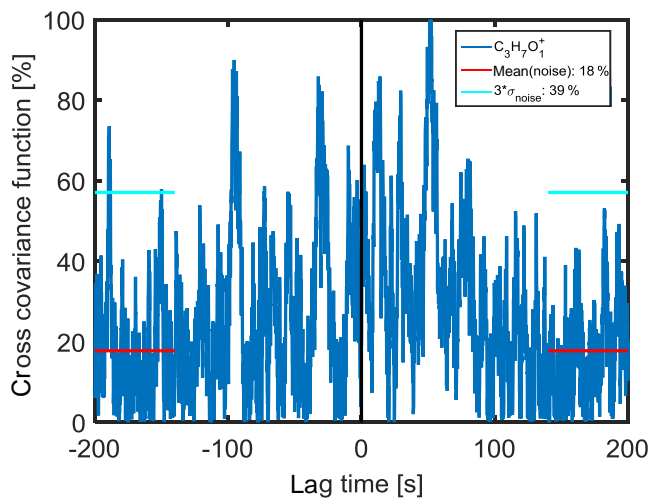

Figure A5. Thirty-minute absolute normalized cross covariance function of $\mathrm{C}_{3} \mathrm{H}_{7} \mathrm{O}_{1}^{+}$from 15 June 2012, 14:15. The red lines at the corners of the plot indicate the average noise, while the cyan lines are the $3 \sigma_{\text {noise }}$ threshold (in the legend the $39 \%$ represents just the $3 \sigma_{\text {noise }}$, while in the plot it is added to the mean noise). Taking the absolute of a CCF increases the mean value and thereby reduces the standard deviation of the noise (compare with Fig. A4).

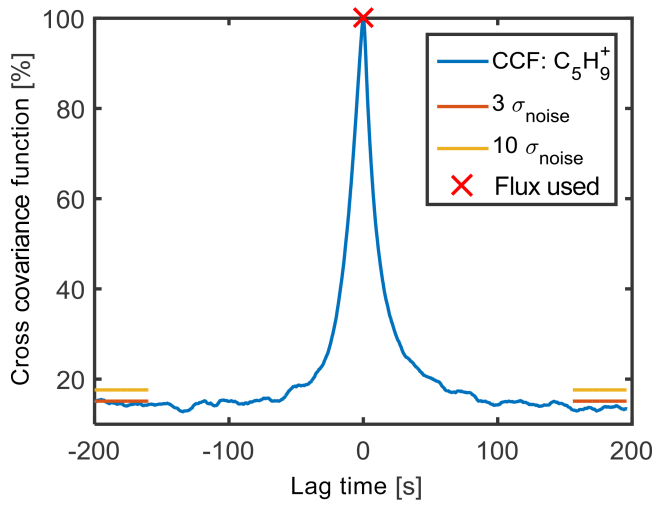

Figure A6. Averaged absolute $\mathrm{CCF}$ for $\mathrm{C}_{5} \mathrm{H}_{9}^{+}$. The flux used is well over the $10 \sigma_{\text {noise }}$ criteria.

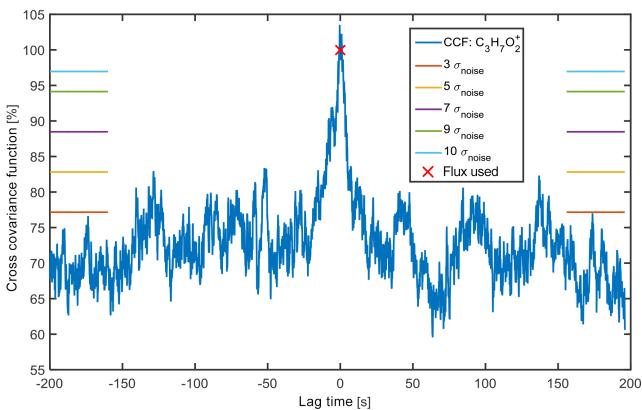

Figure A7. Averaged absolute $\mathrm{CCF}$ for $\mathrm{C}_{3} \mathrm{H}_{7} \mathrm{O}_{2}^{+}$. Due to the constant lag time, the maximum of the CCF is not always used, as this would overestimate the flux. In this case the value used is actually a local minimum between two maxima.

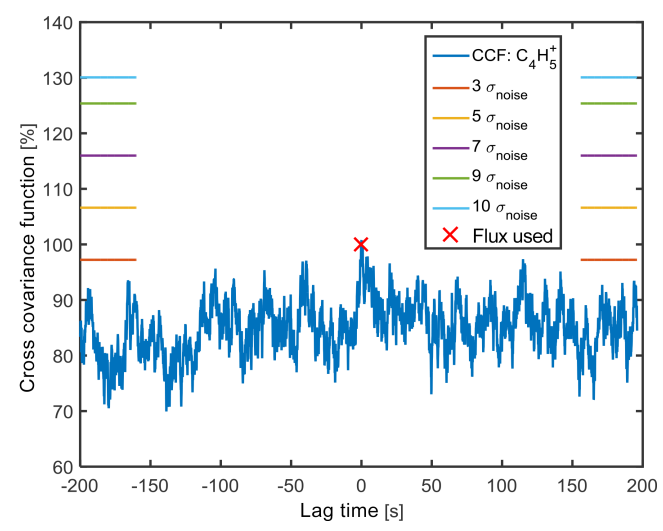

Figure A8. Averaged absolute $\mathrm{CCF}$ of $\mathrm{C}_{4} \mathrm{H}_{5}^{+}$, which fulfilled the $3 \sigma_{\text {noise }}$ criteria.

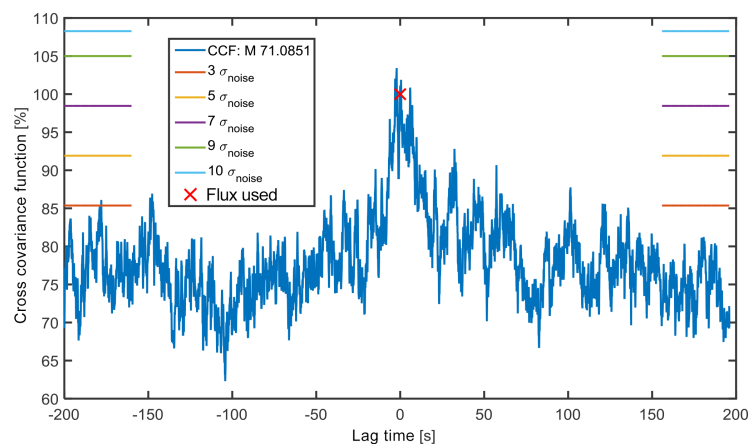

Figure A9. Averaged absolute CCF of mass 71.0851 (could not be identified), which fulfilled the $7 \sigma_{\text {noise }}$ criteria. 
Acknowledgements. We would like to thank Markus Müller for providing the PTR-ToF Data Analyzer and Heikki Junninen and the TofTools team for providing the TofTools. We are further grateful to the Corpo Forestale dello Stato for access to the site. Thanks to all participants of the Bosco Fontana campaign, especially to Joe Acton for discussing and comparing the fluxes measured with PTR-QMS and PTR-ToF and to Ben Langford and Mhairi Coyle for helping with the installation on the tower. The data for the annual mean temperature and precipitation (UDel_AirT_Precip) were provided by the NOAA/OAR/ESRL PSD, Boulder, Colorado, USA, from their website at http://www.esrl.noaa.gov/psd/.

This research received funding from the EC Seventh Framework Programme (collaborative projects "ECLAIRE", grant no. 282910, and "PEGASOS", grant no. 265148) and from the Academy of Finland Centre of Excellence program (project number 272041).

Edited by: K.-E. Min

\section{References}

Acton, W. J. F., Schallhart, S., Langford, B., Valach, A., Rantala, P., Fares, S., Carriero, G., Tillmann, R., Tomlinson, S. J., Dragosits, U., Gianelle, D., Hewitt, C. N., and Nemitz, E.: Canopyscale flux measurements and bottom-up emission estimates of volatile organic compounds from a mixed oak and hornbeam forest in northern Italy, Atmos. Chem. Phys., 16, 7149-7170, doi:10.5194/acp-16-7149-2016, 2016.

Ammann, C., Brunner, A., Spirig, C., and Neftel, A.: Technical note: Water vapour concentration and flux measurements with PTR-MS, Atmos. Chem. Phys., 6, 4643-4651, doi:10.5194/acp6-4643-2006, 2006.

Andronache, C., Chameides, W. L., Rodgers, M. O., Martinez, J., Zimmerman, P., and Greenberg, J.: Vertical distribution of isoprene in the lower boundary layer of the rural and urban southern United States, J. Geophys. Res., 99, 16989-16999, doi:10.1029/94JD01027, 1994.

Baasandorj, M., Millet, D. B., Hu, L., Mitroo, D., and Williams, B. J.: Measuring acetic and formic acid by proton-transferreaction mass spectrometry: sensitivity, humidity dependence, and quantifying interferences, Atmos. Meas. Tech., 8, 13031321, doi:10.5194/amt-8-1303-2015, 2015.

Bloss, C., Wagner, V., Bonzanini, A., Jenkin, M. E., Wirtz, K., Martin-Reviejo, M., and Pilling, M. J.: Evaluation of detailed aromatic mechanisms (MCMv3 and MCMv3.1) against environmental chamber data, Atmos. Chem. Phys., 5, 623-639, doi:10.5194/acp-5-623-2005, 2005.

Boy, M., Mogensen, D., Smolander, S., Zhou, L., Nieminen, T., Paasonen, P., Plass-Dülmer, C., Sipilä, M., Petäjä, T., Mauldin, L., Berresheim, H., and Kulmala, M.: Oxidation of $\mathrm{SO}_{2}$ by stabilized Criegee intermediate ( $\mathrm{sCI}$ ) radicals as a crucial source for atmospheric sulfuric acid concentrations, Atmos. Chem. Phys., 13, 3865-3879, doi:10.5194/acp-13-3865-2013, 2013.

Businger, J. A. and Oncley, S. P.: Flux measurement with conditional sampling, J. Atmos. Ocean. Tech., 7, 349-352, 1990.

Chebbi, A. and Carlier, P.: Carboxylic acids in the troposphere, occurrence, sources, and sinks: A review, Atmos. Environ., 30, 4233-4249, doi:10.1016/1352-2310(96)00102-1, 1996.
Dalponte, M., Bruzzone, L. and Gianelle, D.: Fusion of hyperspectral and LIDAR remote sensing data for classification of complex forest areas, Geosci. Remote Sens., 46, 1416-1427, 2008.

Damian, V., Sandu, A., Damian, M., Potra, F., and Carmichael, G. R.: The kinetic preprocessor KPP - a software environment for solving chemical kinetics, Comput. Chem. Eng., 26, 1567-1579, 2002.

Damköhler, G.: Der Einfluss der Turbulenz auf die Flammengeschwindigkeit in Gasgemischen, Z. Elektrochem. Angew. P., 46, 601-626, 1940.

de Gouw, J. A. and Warneke, C.: Measurements of volatile organic compounds in the earth's atmosphere using proton-transferreaction mass spectrometry, Mass Spectrom. Rev., 26, 223-257, doi:10.1002/mas.20119, 2006.

de Gouw, J. A., Howard, C. J., Custer, T. G., Baker, B. M., and Fall, R.: Proton-transfer chemical-ionization mass spectrometry allows real-time analysis of volatile organic compounds released from cutting and drying of crops, Environ. Sci. Technol., 34, 2640-2648, 2000.

Derwent, R. G., Jenkin, M. E., Saunders, S. M., Pilling, M. J., Simmonds, P. G., Passant, N. R., Dollard, G. J., Dumitrean, P., and Kent, A.: Photochemical ozone formation in north west Europe and its control, Atmos. Environ., 37, 1983-1991, 2003.

Dolman, A. J.: Estimates of roughness length and zero plane displacement for a foliated and non-foliated oak canopy, Agr. Forest Meteorol., 36, 241-248, 1986.

EPA: Chemical Summary for Acetaldehyde, EPA 749-F-94003a, Office of Pollution Prevention and Toxics, available at: http://onlinelibrary.wiley.com/doi/10.1002/9781118747926. app1/pdf (last access: 13 October 2015), 1994.

Fall, R.: Reactive hydrocarbons in the atmosphere, Academic Press, San Diego 41-96, 1999.

Fall, R., Karl, T., Jordan, A. and Lindinger, W.: Biogenic C5 VOCs: release from leaves after freeze-thaw wounding and occurrence in air at a high mountain observatory, Atmos. Environ., 35, 39053916, 2001.

Fares, S., Paoletti, E., Loreto, F., and Brilli, F.: Bidirectional Flux of Methyl Vinyl Ketone and Methacrolein in Trees with Different Isoprenoid Emission under Realistic Ambient Concentrations, Environ. Sci. Technol., 49, 7735-7742, doi:10.1021/acs.est.5b00673, 2015.

Fehsenfeld, F., Calvert, J., Fall, R., Goldan, P., Guenther, A. B., Hewitt, C. N., Lamb, B., Liu, S., Trainer, M., Westberg, H., and Zimmerman, P.: Emissions of volatile organic compounds from vegetation and the implications for atmospheric chemistry, Global Biogeochem. Cy., 6, 389-430, 1992.

Foken, T. and Wichura, B.: Tools for quality assessment of surfacebased flux measurements, Agr. Forest Meteorol., 78, 83-105, 1996.

Fuentes, J. D., Wang, D., Neumann, H. H., Gillespie, T. J., Den Hartog, G. and Dann, T. F.: Ambient biogenic hydrocarbons and isoprene emissions from a mixed deciduous forest, J. Atmos. Chem., 25, 67-95, 1996.

Fuentes, J. D., Gu, L., Lerdau, M., Atkinson, R., Baldocchi, D., Bottenheim, J. W., Ciccioli, P., Lamb, B., Geron, C., Guenther, A. B., Sharkey, T. D., and Stockwell W.: Biogenic Hydrocarbons in the Atmospheric Boundary Layer: A Review, B. Am. Meteorol. Soc., 81, 1537-1575, 2000. 
Garland, J. A.: Dry Deposition of Sulfur-Dioxide to Land and Water Surfaces, P. Roy. Soc. A-Math. Phy., 354, 245-268, 1977.

Geron, C., Guenther, A. B., Greenberg, J., Loescher, H. W., Clark, D., and Baker, B.: Biogenic volatile organic compound emissions from a lowland tropical wet forest in Costa Rica, Atmos. Environ., 36, 3793-3802, 2002.

Goldan, P. D., Kuster, W. C., Fehsenfeld, F. C., and Montzka, S. A.: Hydrocarbon measurements in the southeastern United States: The Rural Oxidants in the Southern Environment (ROSE) Program 1990, J. Geophys. Res., 100, 25945-25963, doi:10.1029/95JD02607, 1995.

Goldstein, A. and Schade, G. W.: Quantifying biogenic and anthropogenic contributions to acetone mixing ratios in a rural environment, Atmos. Environ., 34, 4997-5006, 2000.

Graus, M., Müller, M., and Hansel, A.: High resolution PTR-TOF: quantification and formula confirmation of VOC in real time, $\mathrm{J}$. Am. Soc. Mass Spectr., 21, 1037-1044, 2010.

Guenther, A. B., Hewitt, C. N., Erickson, D., Fall, R., Geron, C., Graedel, T., Harley, P., Klinger, L., Lerdau, M., McKay, W. A., Pierce, T., Scholes, B., Steinbrecher, R., Tallamraju, R., Taylor, J., and Zimmerman, P., A global model of natural volatile organic compound emissions, J. Geophys. Res., 100, 8873-8892, doi:10.1029/94JD02950, 1995.

Guenther, A. B., Greenberg, J., Harley, P., Helmig, D., Klinger, L., Vierling, L., Zimmerman, P., and Geron, C.: Leaf, branch, stand and landscape scale measurements of volatile organic compound fluxes from U.S. woodlands, Tree Physiol., 16, 17-24, doi:10.1093/treephys/16.1-2.17, 1996.

Guenther, A. B., Jiang, X., Heald, C. L., Sakulyanontvittaya, T., Duhl, T., Emmons, L. K., and Wang, X.: The Model of Emissions of Gases and Aerosols from Nature version 2.1 (MEGAN2.1): an extended and updated framework for modeling biogenic emissions, Geosci. Model Dev., 5, 1471-1492, doi:10.5194/gmd-51471-2012, 2012.

Harley, P. C., Monson, R. K., and Lerdau, M. T.: Ecological and evolutionary aspects of isoprene emission from plants, Oecologia, 118, 109-123, 1999.

Heikes, B. G., Chang, W. N , Pilson, M. E. Q., Swift, E., Singh, H. B., Guenther, A., Jacob, D. J., Field, B. D., Fall, R., Riemer, D., and Brand, L.: Atmospheric methanol budget and ocean implication, Global Biogeochem. Cy., 16, 1133, doi:10.1029/2002GB001895, 2002.

Hens, K., Novelli, A., Martinez, M., Auld, J., Axinte, R., Bohn, B., Fischer, H., Keronen, P., Kubistin, D., Nölscher, A. C., Oswald, R., Paasonen, P., Petäjä, T., Regelin, E., Sander, R., Sinha, V., Sipilä, M., Taraborrelli, D., Tatum Ernest, C., Williams, J., Lelieveld, J., and Harder, H.: Observation and modelling of $\mathrm{HO}_{\mathrm{x}}$ radicals in a boreal forest, Atmos. Chem. Phys., 14, 8723-8747, doi:10.5194/acp-14-8723-2014, 2014

Herbig, J., Müller, M., Schallhart, S., Titzmann, T., Graus, M., and Hansel, A.: On-line breath analysis with PTR-TOF, J. Breath Res., 3, 027004, doi:10.1088/1752-7155/3/2/027004, 2009.

Holopainen, J. K.: Multiple functions of inducible plant volatiles, Trends Plant Sci., 9, 529-533, 2004.

Holzinger, R., Jordan, A., Hansel, A., and Lindinger W.: Methanol measurements in the lower troposphere near Innsbruck $\left(047^{\circ} 16 / \mathrm{N} ; 011^{\circ} 24 / \mathrm{E}\right)$, Austria, Atmos. Enviro., 35, 25252532, 2001 .
Horst, T. W.: A simple formula for attenuation of eddy fluxes measured with first-order-response scalar sensors, Bound.-Lay. Meteorol., 82, 219-233, 1997.

Jacob, D. J., Field, B. D., Jin, E. M., Bey, I., Li, Q., Logan, J. A., Yantosca, R. M., and Singh, H. B.: Atmospheric budget of acetone, J. Geophys. Res.-Atmos., 107, 4100, doi:10.1029/2001JD000694, 2002.

Janson, R., De Serves, C., and Romero, R.: Emission of isoprene and carbonyl compounds from a boreal forest and wetland in Sweden, Agr. Forest Meteorol., 98, 671-681, 1999.

Jardine, K. J., Monson, R. K., Abrell, L., Saleska, S. R., Arneth, A., Jardine, A., Ishida, F. Y., Serrano, A. M. Y., Artaxo, P., Karl, T., Fares, S., Goldstein, A., Loreto, F., and Huxman, T.: Within-plant isoprene oxidation confirmed by direct emissions of oxidation products methyl vinyl ketone and methacrolein, Glob. Change Biol., 18, 973-984, doi:10.1111/j.1365-2486.2011.02610.x, 2012.

Jenkin, M. E., Saunders, S. M., and Pilling, M. J.: The tropospheric degradation of volatile organic compounds: A protocol for mechanism development, Atmos. Environ., 31, 81-104, 1997.

Jordan, A., Haidacher, S., Hanel, G., Hartungen, E., Märk, L., Seehauser, H., Schottkowsky, R., Sulzer, P., and Märk, T. D.: A high resolution and high sensitivity proton-transfer-reaction time-offlight mass spectrometer (PTR-TOF-MS), Int. J. Mass Spectrom., 286, 122-128, 2009.

Junninen, H., Ehn, M., Petäjä, T., Luosujärvi, L., Kotiaho, T., Kostiainen, R., Rohner, U., Gonin, M., Fuhrer, K., Kulmala, M., and Worsnop, D. R.: A high-resolution mass spectrometer to measure atmospheric ion composition, Atmos. Meas. Tech., 3, 10391053, doi:10.5194/amt-3-1039-2010, 2010.

Kaimal, J. C. and Finnigan, J. J.: Atmospheric Boundary Layer Flows: Their Structure and Measurement, Oxford University press, New York, USA, 1994.

Karl, T., Guenther, A. B., Jordan, A., Fall, R., and Lindinger, W.: Eddy covariance measurement of biogenic oxygenated VOC emissions from hay harvesting, Atmos. Environ., 35, 491-495, doi:10.1016/S1352-2310(00)00405-2, 2001.

Karl, T. G., Spirig, C., Rinne, J., Stroud, C., Prevost, P., Greenberg, J., Fall, R., and Guenther, A.: Virtual disjunct eddy covariance measurements of organic compound fluxes from a subalpine forest using proton transfer reaction mass spectrometry, Atmos. Chem. Phys., 2, 279-291, doi:10.5194/acp-2-279-2002, 2002.

Karl, T., Guenther, A., Turnipseed, A., Tyndall, G., Artaxo, P., and Martin, S.: Rapid formation of isoprene photo-oxidation products observed in Amazonia, Atmos. Chem. Phys., 9, 7753-7767, doi:10.5194/acp-9-7753-2009, 2009.

Karl, T., Harley, P., Emmons, L., Thornton, B., Guenther, A., Basu, C., Turnipseed, A., and Jardine, K.: Efficient Atmospheric Cleansing of Oxidized Organic Trace Gases by Vegetation, Science, 330, 816-819, doi:10.1126/science.1192534, 2010.

Kaser, L., Karl, T., Guenther, A., Graus, M., Schnitzhofer, R., Turnipseed, A., Fischer, L., Harley, P., Madronich, M., Gochis, D., Keutsch, F. N., and Hansel, A.: Undisturbed and disturbed above canopy ponderosa pine emissions: PTR-TOF-MS measurements and MEGAN 2.1 model results, Atmos. Chem. Phys., 13, 11935-11947, doi:10.5194/acp-13-11935-2013, 2013.

Kesselmeier, J. and Staudt, M.: Biogenic volatile organic compounds (VOC): an overview on emission, physiology and ecology, J. Atmos. Chem., 33, 23-88, 1999. 
König, G., Brunda, M., Puxbaum, H., Hewitt, C. N., Duckham, S. C., and Rudolph, J.: Relative contribution of oxygenated hydrocarbons to the total biogenic VOC emissions of selected midEuropean agricultural and natural plant species, Atmos. Environ., 29, 861-874, 1995.

Kulmala, M., Toivonen, A., Mäkelä, J., and Laaksonen, A.: Analysis of the growth of nucleation mode particles observed in boreal forest, Tellus, 50B, 449-462, 1998.

Laffineur, Q., Aubinet, M., Schoon, N., Amelynck, C., Müller, J.F., Dewulf, J., Van Langenhove, H., Steppe, K., and Heinesch, B.: Abiotic and biotic control of methanol exchanges in a temperate mixed forest, Atmos. Chem. Phys., 12, 577-590, doi:10.5194/acp-12-577-2012, 2012.

Lamb, B., Westberg, H., and Allwine, G.: Biogenic hydrocarbon emissions from decidous and coniferous trees in the United States, J. Geophys. Res., 90, 2380-2390, 1985.

Langford, B., Acton, W., Ammann, C., Valach, A., and Nemitz, E.: Eddy-covariance data with low signal-to-noise ratio: time-lag determination, uncertainties and limit of detection, Atmos. Meas. Tech., 8, 4197-4213, doi:10.5194/amt-8-4197-2015, 2015.

Lawrence, M. G: The Relationship between Relative Humidity and the Dewpoint Temperature in Moist Air: A Simple Conversion and Applications, B. Am. Meteorol. Soc., 86, 225-233, doi:10.1175/BAMS-86-2-225, 2005.

Lee, X., Massman, W., and Law, B.: Handbook of Micrometeorology: A Guide for Surface Flux Measurements and Analysis, Kluwer Academic Publisher, Dordrecht, 2004.

Liu, Y. J., Herdlinger-Blatt, I., McKinney, K. A., and Martin, S. T.: Production of methyl vinyl ketone and methacrolein via the hydroperoxyl pathway of isoprene oxidation, Atmos. Chem. Phys., 13, 5715-5730, doi:10.5194/acp-13-5715-2013, 2013.

Madronich, S.: UV radiation in the natural and perturbed atmosphere, in: Environmental Effects of UV (Ultraviolet) Radiation, 17-69, CRC Press, Boca Raton, 1993.

Madronich, S. and Flocke, S.: The role of solar radiation in atmospheric chemistry, The Handbook of Environmental Chemistry, Vol. 2. Springer, Berlin, 1-26, 1999.

Mammarella, I., Launiainen, S., Gronholm, T., Keronen, P., Pumpanen, J., Rannik, Ü., and Vesala, T.: Relative humidity effect on the high-frequency attenuation of water vapor flux measured by a closed-path eddy covariance system, J. Atmos. Ocean. Tech., 26, 1856-1866, 2009.

Misztal, P. K., Nemitz, E., Langford, B., Di Marco, C. F., Phillips, G. J., Hewitt, C. N., MacKenzie, A. R., Owen, S. M., Fowler, D., Heal, M. R., and Cape, J. N.: Direct ecosystem fluxes of volatile organic compounds from oil palms in South-East Asia, Atmos. Chem. Phys., 11, 8995-9017, doi:10.5194/acp-11-89952011, 2011.

Mogensen, D., Gierens, R., Crowley, J. N., Keronen, P., Smolander, S., Sogachev, A., Nölscher, A. C., Zhou, L., Kulmala, M., Tang, M. J., Williams, J., and Boy, M.: Simulations of atmospheric $\mathrm{OH}, \mathrm{O}_{3}$ and $\mathrm{NO}_{3}$ reactivities within and above the boreal forest, Atmos. Chem. Phys., 15, 3909-3932, doi:10.5194/acp-15-39092015, 2015.

Monks, P. S., Granier, C., Fuzzi, S., Stohl, A.,Williams, M. L., Akimoto, H., Amann, M., Baklanov, A., Baltensperger, U., Bey, I., Blake, N., Blake, R. S., Carslaw, K., Cooper, O. R., Dentener, F., Fowler, D., Fragkou, E., Frost, G. J., Generoso, S., Ginoux, P., Grewe, V., Guenther, A., Hansson, H. C., Henne, S., Hjorth,
J., Hofzumahaus, A., Huntrieser, H., Isaksen, I. S. A., Jenkin, M. E., Kaiser, J., Kanakidou, M., Klimont, Z., Kulmala, M., Laj, P., Lawrence, M. G., Lee, J. D., Liousse, C., Maione, M., McFiggans, G., Metzger, A., Mieville, A., Moussiopoulos, N., Orlando, J. J., O'Dowd, C. D., Palmer, P. I., Parrish, D. D., Petzold, A., Platt, U., Pöschl, U., Prévôt, A. S. H., Reeves, C. E., Reimann, S., Rudich, Y., Sellegri, K., Steinbrecher, R., Simpson, D., ten Brink, H., Theloke, J., van derWerf, G. R., Vautard, R., Vestreng, V., Vlachokostas, C., and von Glasow, R.: Atmospheric composition change - global and regional air quality, Atmos. Environ., 43, 5268-5350, doi:10.1016/j.atmosenv.2009.08.021, 2009.

Moore, C. J.: Frequency response corrections for eddy correlation systems, Bound.-Lay. Meteorol., 37, 17-35, 1986.

Müller, M., Graus, M., Ruuskanen, T. M., Schnitzhofer, R., Bamberger, I., Kaser, L., Titzmann, T., Hörtnagl, L., Wohlfahrt, G., Karl, T., and Hansel, A.: First eddy covariance flux measurements by PTR-TOF, Atmos. Meas. Tech., 3, 387-395, doi:10.5194/amt-3-387-2010, 2010.

Müller, M., Mikoviny, T., Jud, W., D’Anna, B., and Wisthaler, A.: A new software tool for the analysis of high resolution PTR-TOF mass spectra, Chemometrics and Intelligent Laboratory Systems, 127, 158-165, 2013.

Naik, V., Fiore, A. M., Horowitz, L. W., Singh, H. B., Wiedinmyer, C., Guenther, A., de Gouw, J. A., Millet, D. B., Goldan, P. D., Kuster, W. C., and Goldstein, A.: Observational constraints on the global atmospheric budget of ethanol, Atmos. Chem. Phys., 10, 5361-5370, doi:10.5194/acp-10-5361-2010, 2010.

Nemitz, E., Hargreaves, K. J., Neftel, A., Loubet, B., Cellier, P., Dorsey, J. R., Flynn, M., Hensen, A., Weidinger, T., Meszaros, R., Horvath, L., Dämmgen, U., Frühauf, C., Löpmeier, F. J., Gallagher, M. W., and Sutton, M. A.: Intercomparison and assessment of turbulent and physiological exchange parameters of grassland, Biogeosciences, 6, 1445-1466, doi:10.5194/bg-61445-2009, 2009.

Nguyen, T. B., Crounse, J. D., Teng, A. P., St. Clair, J. M., Paulot, F., Wolfe, G. M., and Wennberg, P. O.: Rapid deposition of oxidized biogenic compounds to a temperate forest, P. Natl. Acad. Sci. USA, 112, E392-E401, doi:10.1073/pnas.1418702112, 2015.

Nordbo, A., Kekäläinen, P., Siivola, E., Lehto, R., Vesala, T., and Timonen, J.: Tube transport of water vapor with condensation and desorption, Appl. Phys. Lett., 102, 19, doi:10.1063/1.4804639, 2013.

Nordbo, A., Kekäläinen, P., Siivola, E., Mammarella, I., Timonen, J., and Vesala, T.: Sorption-Caused Attenuation and Delay of Water Vapor Signals in Eddy-Covariance Sampling Tubes and Filters, J. Atmos. Ocean. Technol., 31, 2629-2649, 2014.

Owen, P. R. and Thompson, W. R.: Heat transfer across rough surfaces, J. Fluid Mech., 15, 321-334, 1963.

Paasonen, P., Asmi, A., Petäjä, T., Kajos, M. K., Äijälä, M., Junninen, H., Holst, T., Abbatt, J. P. D., Arneth, A., Birmili, W. van der Gon, H. D., Hamed, A., Hoffer, A., Laakso, L., Laaksonen, A., Leaitch, W. R., Plass-Dülmer, C., Pryor, S. C., Räisänen, P., Swietlicki, E., Wiedensohler, A., Worsnop, D. R., Kerminen, V.-M. and Kulmala, M.: Warming induced increase in aerosol number concentration likely to moderate climate change, Nat. Geosci., 6, 438-442, 2013.

Park, J.-H., Goldstein, A. H., Timkovsky, J., Fares, S., Weber, R., Karlik, J., and Holzinger R.: Active Atmosphere-Ecosystem Exchange of the Vast Majority of Detected Volatile Organic 
Compounds, Science, 9, 643-647, doi:10.1126/science.1235053, 2013.

Paulot, F., Wunch, D., Crounse, J. D., Toon, G. C., Millet, D. B., DeCarlo, P. F., Vigouroux, C., Deutscher, N. M., González Abad, G., Notholt, J., Warneke, T., Hannigan, J. W., Warneke, C., de Gouw, J. A., Dunlea, E. J., De Mazière, M., Griffith, D. W. T., Bernath, P., Jimenez, J. L., and Wennberg, P. O.: Importance of secondary sources in the atmospheric budgets of formic and acetic acids, Atmos. Chem. Phys., 11, 1989-2013, doi:10.5194/acp-11-1989-2011, 2011.

Peräkylä, O., Vogt, M., Tikkanen, O.-P., Laurila, T., Kajos, M. K., Rantala, P. A., Patokoski, J., Aalto, J., Yli-Juuti, T., Ehn, M., Sipilä, M., Paasonen, P., Rissanen, M., Nieminen, T., Taipale, R., Keronen, P., Lappalainen, H. K., Ruuskanen, T. M., Rinne, J., Kerminen, V.-M., Kulmala, M., Bäck, J., and Petäjä, T.: Monoterpenes' oxidation capacity and rate over a boreal forest: temporal variation and connection to growth of newly formed particles, Boreal Environ. Res., 19 supp. B, 293-310, 2014.

Petäjä, T., Mauldin, III, R. L., Kosciuch, E., McGrath, J., Nieminen, T., Paasonen, P., Boy, M., Adamov, A., Kotiaho, T., and Kulmala, M.: Sulfuric acid and $\mathrm{OH}$ concentrations in a boreal forest site, Atmos. Chem. Phys., 9, 7435-7448, doi:10.5194/acp9-7435-2009, 2009.

Potosnak, M. J., LeStourgeon, L., Pallardy, S. G., Hosman, K. P., Gu, L., Karl, T., Geron, C., and Guenther, A. B.: Observed and modeled ecosystem isoprene fluxes from an oak-dominated temperate forest and the influence of drought stress, Atmos. Environ., 84, 314-322, 2014.

Rannik, Ü.: On the surface layer similarity at a complex forest site, J. Geophys. Res., 103, 8685-8697, doi:10.1029/98JD00086, 1998.

Rantala, P., Taipale, R., Aalto, J., Kajos, M. K., Patokoski, J., Ruuskanen, T. M., and Rinne, J.: Continuous flux measurements of VOCs using PTR-MS - reliability and feasibility of disjunct-eddy-covariance, surface-layer-gradient, and surfacelayer-profile methods, Boreal Environ. Res., 19 (suppl. B), 87107, 2014.

Rantala, P., Aalto, J., Taipale, R., Ruuskanen, T. M., and Rinne, J.: Annual cycle of volatile organic compound exchange between a boreal pine forest and the atmosphere, Biogeosciences, 12, 5753-5770, doi:10.5194/bg-12-5753-2015, 2015.

Rasmussen, R. A.: Isoprene: identified as a forest-type emission to the atmosphere, Environ. Sci. Technol., 4, 667-671, 1970.

Riemer, D., Pos, W., Milne, P., Farmer, C., Zika, R., Apel, E., Olszyna, K., Kliendienst, T., Lonneman, W., Bertman, S., Shepson, P., and Starn, T.: Observations of nonmethane hydrocarbons and oxygenated volatile organic compounds at a rural site in the southeastern United States, J. Geophys. Res.-Atmos., 103, 28111-28128, 1998

Riipinen, I., Yli-Juuti, T., Pierce, J. R., Petäjä, T., Worsnop, D. R., Kulmala, M., and Donahue, N. M.: The contribution of organics to atmospheric nanoparticle growth, Nat. Geosci., 5, 453-458, 2012.

Rinne, J. and Ammann, C.: Disjunct eddy covariance method, in: Eddy Covariance Handbook, edited by: Aubinet, M., Vesala, T., and Papale, D., Springer, New York, USA, doi:10.1007/978-94007-2351-1, 291-307, 2012.
Rinne, J., Guenther, A. B., Warneke, C., de Gouw, J. A., and Luxembourg, S. L.: Disjunct eddy covariance technique for trace gas flux measurements, Geophys. Res. Lett., 28, 3139-3142, 2001.

Rinne, J., Taipale, R., Markkanen, T., Ruuskanen, T. M., Hellén, H., Kajos, M. K., Vesala, T., and Kulmala, M.: Hydrocarbon fluxes above a Scots pine forest canopy: measurements and modeling, Atmos. Chem. Phys., 7, 3361-3372, doi:10.5194/acp-73361-2007, 2007.

Rinne, J., Markkanen, T., Ruuskanen, T. M., Petäjä, T., Keronen, P., Tang, M. J., Crowley, J. N., Rannik, Ü., and Vesala, T.: Effect of chemical degradation on fluxes of reactive compounds - a study with a stochastic Lagrangian transport model, Atmos. Chem. Phys., 12, 4843-4854, doi:10.5194/acp-12-4843-2012, 2012.

Rivera-Rios, J. C., Nguyen, T. B., Crounse, J. D., Jud, W. St. Clair, J. M., Mikoviny, T., Gilman, J. B., Lerner, B. M., Kaiser, J. B., de Gouw, J., Wisthaler, A., Hansel, A., Wennberg P. O., Seinfeld, J. H., and Keutsch, F. N.: Conversion of hydroperoxides to carbonyls in field and laboratory instrumentation: Observational bias in diagnosing pristine versus anthropogenically controlled atmospheric chemistry, Geophys. Res. Lett., 41, 86458651, doi:10.1002/2014GL061919, 2014.

Roberts, J. M.: The atmospheric chemistry of organic nitrates, Atmos. Environ., 24A, 243-287, 1990.

Rosenstiel, T. N., Fisher, A. J., Fall, R., and Monson, R. K.: Differential accumulation of dimethylallyl diphosphate in leaves and needles of isoprene-and methylbutenol-emitting and nonemitting species, Plant Physiol., 129, 1276-1284, 2002.

Ruuskanen, T. M., Müller, M., Schnitzhofer, R., Karl, T., Graus, M., Bamberger, I., Hörtnagl, L., Brilli, F., Wohlfahrt, G., and Hansel, A.: Eddy covariance VOC emission and deposition fluxes above grassland using PTR-TOF, Atmos. Chem. Phys., 11, 611-625, doi:10.5194/acp-11-611-2011, 2011.

Saunders, S. M., Jenkin, M. E., Derwent, R. G., and Pilling, M. J.: Protocol for the development of the Master Chemical Mechanism, MCM v3 (Part A): tropospheric degradation of nonaromatic volatile organic compounds, Atmos. Chem. Phys., 3, 161-180, doi:10.5194/acp-3-161-2003, 2003.

Scala, A., Allmann, S., Mirabella, R., Haring, M. A., and Schuurink, R. C.: Green leaf volatiles: a plant's multifunctional weapon against herbivores and pathogens, Int. J. Molecular Sci., 14, 17781-17811, 2013.

Singh, H. B., O’Hara, D., Herlth, D., Sachse, W., Blake, D. R., Bradshaw, J. D., Kanakidou, M., and Crutzen P. J.: Acetone in the atmosphere: Distribution, sources, and sinks, J. Geophys. Res., 99, 1805-1819, doi:10.1029/93JD00764, 1994.

Singh, H. B., Kanakidou, M., Crutzen, P. J., and Jacob, D. J.: High concentrations and photochemical fate of oxygenated hydrocarbons in the global troposphere, Nature, 378, 50-54, 1995.

Taipale, R., Ruuskanen, T. M., and Rinne, J.: Lag time determination in DEC measurements with PTR-MS, Atmos. Meas. Tech., 3, 853-862, doi:10.5194/amt-3-853-2010, 2010.

Tunved, P., Hansson, H.-C., Kerminen, V.-M., Ström, J., Dal Maso, M., Lihavainen, H., Viisanen, Y., Aalto, P. P., Komppula, M., and Kulmala, M.: High natural aerosol loading over boreal forests, Science, 312, 261-263, 2006.

Vickers, D. and Mahrt, L.: Quality Control and Flux Sampling Problems for Tower and Aircraft Data, J. Atmos. Ocean. Tech., 14, 512-526, 1997. 
Warneke, C., Luxembourg, S. L., de Gouw, J. A., Rinne, J., Guenther, A. B., and Fall, R.: Disjunct eddy covariance measurements of oxygenated volatile organic compounds fluxes from an alfalfa field before and after cutting, J. Geophys. Res., 107, D8, doi:10.1029/2001JD000594, 2002.

Webb, E. K., Pearman, G. I., and Leuning, R.: Correction of flux measurements for density effects due to heat and water vapour transfer, Q. J. Roy. Meteor. Soc., 106, 85-100, 1980.

Willmott, C. J. and Matsuura, K.: Terrestrial Air Temperature: 1900-2010 Gridded Monthly Time Series (Version 3.01), available at: http://climate.geog.udel.edu/ climate/html_ pages/Global2011/README.GlobalTsT2011.html, (last access: 21 August 2015), 2012a.

Willmott, C. J. and Matsuura, K.: Terrestrial Precipitation: 19002010 Gridded Monthly Time Series (Version 3.01), available at: http://climate.geog.udel.edu/ climate/html_pages/Global2011/ README.GlobalTsP2011.html, (last access: 21 August 2015), 2012b.
Wilson, K. B. and Baldocchi, D. D.: Comparing independent estimates of carbon dioxide exchange over 5 years at a deciduous forest in the southeastern United States, J. Geophys. Res., 106, 34167-34178, 2001.

Wohlfahrt, G., Amelynck, C., Ammann, C., Arneth, A., Bamberger, I., Goldstein, A. H., Gu, L., Guenther, A., Hansel, A., Heinesch, B., Holst, T., Hörtnagl, L., Karl, T., Laffineur, Q., Neftel, A., McKinney, K., Munger, J. W., Pallardy, S. G., Schade, G. W., Seco, R., and Schoon, N.: An ecosystem-scale perspective of the net land methanol flux: synthesis of micrometeorological flux measurements, Atmos. Chem. Phys., 15, 7413-7427, doi:10.5194/acp-15-7413-2015, 2015. 